Revista lus et Praxis, Año 19, № 2, 2013, pp. 123 - 178

ISSN 0717 - 2877

Universidad de Talca - Facultad de Ciencias Jurídicas y Sociales

"Protección de la salud, acceso a los medicamentos y deficiencias del mercado.

Hacia un derecho social plurivalente en el marco de una economía social de mercado"

Julio Alvear Téllez

\title{
PROTECCIÓN DE LA SALUD, ACCESO A \\ LOS MEDICAMENTOS Y DEFICIENCIAS DEL MERCADO. HACIA UN DERECHO SOCIAL PLURIVALENTE EN EL MARCO DE UNA ECONOMÍA SOCIAL DE MERCADO*
}

\author{
HeAlth PROTECTION, aCCESS tO MEDICINES AND MARKET FAILURES. \\ A MOTION FOR A COMPLETE WELFARE RIGHTS WITHIN THE FRAMEWORK OF A \\ SOCIAL MARKET ECONOMY
}

Julio Alvear Téllez

\begin{abstract}
RESUMEN
El presente trabajo evalúa las deficiencias del mercado para satisfacer el derecho a la protección de la salud en uno de sus componentes esenciales: el acceso a los medicamentos. Deficiencias provenientes, por una parte, de la errada consideración del mercado como ideología y, por otra, de su funcionamiento y expansión en Chile. Frente a este diagnóstico se propone considerar la protección de la salud como un derecho social plurivalente capaz de armonizar distintos componentes jurídicos de realización: derechos exigencias, derechos libertades y deberes estatales, en conformidad con el actual estatuto constitucional de la salud. Realización que debe extenderse al interior del mercado de medicamentos sobre la base del paradigma

de una economía social de mercado, que respetando en lo esencial la lógica de la iniciativa privada y del libre intercambio, la completa con una regulación compensatoria que subordina el lucro a las exigencias de interés general.
\end{abstract}

\section{ABSTRACT}

The present work evaluates the shortcomings of the market to satisfy the right of health protection in one of its essential components: access to medicines. The deficiencies come from, on the one hand, the incorrect consideration of the market as an ideology, and on the other, its operation and expansion in Chile. Facing this diagnosis, the author proposes to consider the protection of health as welfare right complete, capable of harmonizing different legal components: rights as requirements, rights as liberties, and positive State duties, in accordance with the current health constitutional regulation. That should extend to the interior of the drug market on the basis of the paradigm of a social market economy. While essentially respecting the logic of private initiative and free exchange, the market paradigm is complemented with a

* Trabajo recibido el 31 de mayo y aprobado el 04 de octubre de 2013.

** Doctor en Derecho, Profesor de Derecho Constitucional y miembro del Centro de Justicia Constitucional de la Facultad de Derecho de la Universidad del Desarrollo. Este artículo es parte de la investigación que se realiza en ejecución del proyecto FONDECYT № 11121218. Dirección: Av. La Plaza 680, Las Condes. Fono: (56 2) 23279 559. Fax: (56 2) 23279 283. Correo electrónico: jalvear@udd.cl. 
compensatory adjustment that subordinates the profits to

general interest requirements.

\section{Palabras Clave}

Protección de la salud, Acceso a los medicamentos, Ideología de mercado,

Deficiencias del mercado, Derechos sociales, Economía social de mercado

\section{KEYWORDS}

Health protection, Access to medicines, Ideology of market, Market failures, Welfare rights, Social market economy

\section{Observaciones PREVIAS}

Desde un punto de vista conceptual, el mercado no tiene ni podría tener un sentido peyorativo. Corresponde incluso a una necesidad histórica en la medida en que designa el ámbito en el que libremente se realiza el tráfico económico al interior de una comunidad. Modernamente ha podido ser definido como un espacio para el intercambio en donde se operan las transacciones de bienes y servicios y se determinan los precios ${ }^{1}$.

Desde el ángulo económico, el mercado es un eficiente sistema de asignación de recursos, por cuanto es capaz de coordinar los planes individuales de los distintos agentes económicos (productores, distribuidores, consumidores, etc.) sobre la base de la libertad y la necesidad, expresada en la concurrencia de la oferta y la demanda que condiciona la cantidad producida de cada bien y su precio $^{2}$. Todo lo cual supone, desde el punto de vista jurídico, el respeto por la imagen maestra (Leit-Bild) del mercado, que veremos algo más delante.

Salvo casos extremos de laissez faire, laissez passer, se debe constatar, con Albert, que las sociedades de mercado reconocen la existencia de bienes no comerciales, cuyo valor queda excluido de la apreciación (y apropiación) por parte de las fuerzas del mercado. Pero es distinto el lugar que ocupan los bienes comerciales (cuya valoración y asignación corresponde solo al mercado) y correlativamente los bienes mixtos (cuya valoración y asignación corresponde también al Estado, por vía de prestación directa o por garantía). Al interior del derecho comunitario europeo, por ejemplo, muchos de los bienes esenciales al hombres son mixtos (vivienda, transporte, enseñanza, salud, etc.), a diferencia del modelo norteamericano, donde quedan sujetos mucho más ampliamente al juego del mercado ${ }^{3}$.

\footnotetext{
${ }^{1}$ Cidoncha, Antonio, La libertad de empresa, Thomson Civitas-Aranzadi-Instituto de Estudios Económicos, Cizur Menor, 2006, p. 128.

2 Mankiw, Nicholas Gregory, Principles of Economics: Principios de Economía (traducción de Ester Rabasco), Mc Graw Hill, México, 1999, pp. 59-60, 266-267.

${ }^{3}$ Albert, Michel, Capitalisme contre capitalisme: Capitalismo contra capitalismo (traducción de José Federico Delos), Paidós, Buenos Aires-Barcelona-México, 1997, pp. 97-102. La distinción, válida en lo
} 
Siendo la salud y los medicamentos bienes esenciales para la población, hay que preguntarse si su transformación en bienes comerciales a través del sistema de libre mercado es un buen mecanismo para su acceso por parte de la población.

La interrogante comporta varios estratos, dada las singulares características del mercado en general, del mercado de medicamentos en particular, y del mercado chileno en especial. Por lo que, avanzando con mayor precisión en la respuesta, ensayaremos una solución desde dos aproximaciones: (a) la ideología del mercado, y (b) el funcionamiento real del mercado. Al interior de cada una de estas aproximaciones, se considerarán dos cuestiones: primero, el problema del acceso a los medicamentos desde la lógica del mercado (como ideología o práctica) y, segundo, los déficit de dicha lógica para satisfacer el acceso a los medicamentos en cuanto derecho social. En el entramado de las respuestas se irán analizando, según corresponda, las categorías conceptuales de carácter técnico que están implicadas, como la noción de "derecho social", "medicamento esencial", "acceso", y otras.

\section{LA PROTECCIÓN DE LA SALUD Y EL ACCESO A LOS MEDICAMENTOS ANTE LA IDEOLOGÍA DEL MERCADO}

Hay un modo de considerar el mercado como ideología y otro como realidad. El mercado como realidad es un fenómeno que exige un marco jurídico coherente que le permita desenvolverse con suficiencia. La doctrina española, recogiendo los aportes del Tribunal Constitucional alemán, se refiere a este propósito a la "imagen maestra" (Leit-Bild) del mercado, la que debe ser siempre configurada / respetada por la legislación para que su funcionamiento opere en regla. Esta imagen maestra es el libre intercambio a través del mecanismo privado de los precios. Lo que en abstracto implica varias garantías de carácter constitucional o legal: libertad económica, propiedad privada, defensa de la libre competencia, defensa de los derechos del consumidor, aseguramiento de un campo razonable de acción para el mercado en la sociedad, justificación de la legislación "contra" el mercado, y freno al ejercicio abusivo de las técnicas de intervención pública en la economía ${ }^{4}$.

sustancial, comporta ciertas matizaciones, pues en la actualidad se observan en el modelo norteamericano tendencias para transformar bienes comerciales en bienes mixtos (la reforma de la salud, por ejemplo), mientras en el modelo europeo se ha experimentado una "liberalización" en la provisión de bienes mixtos clásicos (como la despublicatio de los servicios esenciales, variable según el país). Un panorama general, previo a la crisis del euro, de la tensión entre el principio de libre prestación de servicios y la protección de los servicios de interés general, en MANGiAmel, Stelio, "La liberalización de los servicios en la Unión Europea", Revista de Derecho Constitucional Europeo, № 8, julio-diciembre de 2007, pp. 75-93.

${ }^{4}$ Cidoncha, La libertad de empresa, cit. nota n. 1, pp. 139-155. Decimos "en abstracto" porque esta imagen maestra del mercado debe ser modulada en nuestro país conforme a los principios de nuestra 
La valoración del mercado en sede económica es ambivalente, pues depende del rol que se le asigne al interior del sistema en función de las diferentes teorías económicas (v. gr., la escuela neoclásica, keynesiana, austríaca, etc.).

Pero la valoración del mercado puede extenderse más allá de lo propiamente económico y connotar una cosmovisión de cómo debe ser la sociedad. De este modo, el mercado desorbita sus propias funciones y pasa a ser un meta-criterio definitorio de toda asignación o distribución de bienes humanos y canon primordial de relacionamiento social. Es lo que podemos denominar convencionalmente como ideología del mercado ${ }^{5}$.

Son conocidas a este respecto las investigaciones de autores de dispares tendencias como Dumont, Rosanvallon, Röpke, Polanyi, Piettre y Galbraith. Es posible hacer una conjunción complementaria de algunos de sus aportes si se los mira desde la perspectiva que nos interesa destacar aquí: la ideología de mercado como exceso.

El horizonte que abre Louis Dumont en su estudio sobre la génesis y el apogeo de la ideología económica sirve de oportuno marco referencial ${ }^{6}$. Hay que retener su tesis de que la modernidad, como visión de mundo, requería necesariamente de una "ideología económica" en su tarea de redefinir el universo según los parámetros fáusticos del racionalismo cuantitativo. En ello hay un continuo sorprendente, pero indudable, que va de Locke a Marx ${ }^{7}$.

En este contexto, Rosenvallon escruta el origen de la filosofía que se tejió en torno al mercado dentro de esa misma modernidad ideológica, y la traduce en una primacial emancipación de la economía respecto de la moral cristiana, para luego identificarla con una concepción política y social destinada a estructurar la nueva sociedad como espacio de "auto-regulación" bajo el imperio

Constitución, donde la relación persona-Estado en el ámbito económico está regida primordialmente por el principio de subsidiariedad y los derechos fundamentales basales o concurrentes, tanto los recogidos en el artículo 19 como los referidos en el artículo $5^{\circ}$ inciso $2^{\circ}$. La bibliografía sobre este principio es conocida y amplísima, como lo es la discusión sobre su naturaleza y alcances. Una síntesis reciente de la doctrina chilena en la materia, con oportunos acentos problemáticos, Loo, Martín, "La disciplina del principio de subsidiariedad en Italia y en Chile", Revista de Derecho de la Pontificia Universidad Católica de Valparaíso XXXIII, $2^{\circ}$ semestre de 2009, pp. 416-425.

${ }^{5}$ Empleamos aquí el término "ideología" en su sentido canónico: un subproducto del pensamiento humano, formulado a modo de concepción total de mundo, marcado por el afán de manipular, dominar o fabricar la realidad de acuerdo con las construcciones mentales que de ella se derivan. VALLET DE Gortisolo, Juan, Ideología, Praxis y Mito de la Tecnocracia, Montecorvo, Madrid, 1975, p. 48.

${ }^{6}$ Dumont, Louis, Homo aequalis. Genèse et épanouissement de l'idéologie économique: Homo aequalis. Génesis y apogeo de la ideología económica (traducción de Juan Aranzadi), Taurus, Madrid, 1999.

${ }^{7}$ En los términos de Dumont, es una ruta lineal en lo esencial que va de la emancipación de la economía respecto de lo político (Locke) a una filosofía de la historia donde lo humano depende completamente de la producción (Marx). Dumont, Homo aequalis, cit. nota n. 6, pp. 71-87, 185-226. 
del mercado. La representación de la sociedad como mercado, definida a sí misma a partir de la acumulación de riquezas materiales, encarna en el tiempo la filosofía abstracta pero totalitaria del valor cuantificable . $^{8}$

Sobre este punto específico, Röpke, uno de los padres de la economía social de mercado, denuncia la expulsión del hombre del horizonte de las ciencias económicas por exigencia metodológica. Destaca el falso arte de los "economistas matematizantes", que impulsados por la manía econométrica convierten los medios en fines, confundiendo el crecimiento económico de las cifras con el bienestar general de un país. La ideología de mercado ha convertido la economía en una "física económica" obsesionada por la cantidad, incapaz de mirar la existencia humana en sí mismo considerada. La pasión por los números y fórmulas expresa más que un método: es un ideal, con el que se permite aplanar la realidad y, por ello mismo, falsearla9.

Polanyi se muestra especialmente crítico con el paradigma del homo economicus en cuanto sujeto ideológico que recrea culturalmente la economía de mercado. Para el autor, es una falacia política, económica e histórica asimilar el mejor modo de resolver los problemas económicos con los mecanismos del mercado, por cuanto es el sustento y no la escasez o la acumulación piramidal de riqueza el concepto clave de la economía, al menos desde la perspectiva históri$\mathrm{ca}^{10}$. Piettre, por su parte, prefiere hablar de edad de la "economía dominante", como una de las etapas cíclicas de la historia, apuntando al lado de su activo sus grandes pasivos, como la devastación de los valores humanos no económicos ${ }^{11}$. Galbraith, por su lado, devela cómo la economía de mercado se ha convertido en un eje que paradójicamente desorbita el propio lugar del mercado ${ }^{12}$.

Fruto de la crisis económica que sufre el capitalismo, se ha debatido mucho acerca de la incidencia real de esta ideología en los vectores de dicha crisis, particularmente en el sector financiero y sus consecuencias en la sociedad de consumo $^{13}$. No podemos recomponer aquí la controversia, que incluye no solo

\footnotetext{
${ }^{8}$ Rosanvallon, Pierre, El capitalismo utópico. Historia de la idea de mercado, Ediciones Nueva Visión, Buenos Aires, 2006, pp. 65-77.

${ }^{9}$ RöPKE, Wilhelm, Más allá de la oferta y la demanda, Fomento de Cultura, Valencia, 1960, pp. 150-155, 330-340; RÖPKE, Wilhelm, "La crisis social de nuestro tiempo", Revista de Occidente, Madrid, 1947, pp. 67-68; RÖPKE, Wilhelm, "Civitas humana", Revista de Occidente, Madrid, 1956 pp. 19-24.

${ }^{10}$ Polanyı, Karl, The Livelihood of Man: El sustento del hombre (traducción de Ester Gómez), Mondadori, Barcelona, 1994, pp. 81-85.

${ }^{11}$ Piettre, Andre, Les trois âges de l'économie: Las tres edades de la economía (traducción de Fernando Aguirre), Rialp, Madrid, 1962, pp. 281-309.

12 Galbraith, John Kenneth, Naciones ricas, naciones pobres. Ensayos sobre la persuasión política y económica, Ariel, Barcelona, 1986, pp. 74-76.

${ }_{13}$ Por todos, Chang, Ha-Joon, 23 Things They Don't Tell You About Capitalism, Penguin Books Limited, London, 2010. Una crítica al absurdo moral de la ideología del mercado en clave triunfalista, SANDEL,
} 
cuestiones económicas, políticas y culturales, sino también filosóficas, éticas e incluso terminológicas, como la discusión acerca del "neoliberalismo"14.

En cuanto se refiere a sus resultados y cómo pueden afectar en general el derecho a la protección de la salud y en particular el acceso a los medicamentos, nos parece que la singularidad de esta ideología consiste en atribuir un papel totalizador al mecanismo de mercado al interior de la sociedad, que se extiende por lógica consecuencia a la distribución de los recursos para satisfacer las necesidades básicas.

El mercado es concebido con todas las perfecciones o atributos que la teoría económica asigna al estado impoluto de competencia perfecta: racionalidad de los agentes económicos, atomicidad y transparencia del mercado, homogeneidad de los productos en competencia, libre entrada y salida, y movilidad de los factores de producción ${ }^{15}$. Todas las ventajas de este modelo ideal son trasladadas al mundo real del funcionamiento de los mercados concretos. De tal manera que si a éstos se les deja en manos de su propia lógica, simplemente económica, es dable esperar el máximo beneficio para todos: productores, distribuidores, proveedores y consumidores. Beneficio "máximo" en cuanto al precio, cantidad, calidad, información y satisfacción, porque apodícticamente éste es el fruto de la libre concurrencia armónica de los involucrados en el intercambio.

En el área de la salud y los medicamentos, si el mercado no funciona de acuerdo con este "deber ser", el fallo no es atribuible a su estructura, predefinida como el aparejo más eficiente del ser humano para la asignación de los recursos. El discurso ideológico del mercado sitúa las deficiencias en las débiles condiciones de la pobre realidad, negligente en su tarea de adecuarse a la racionalidad intrínseca y benéfica de aquél.

A través de este modo de leer lo que sucede y debiera suceder con el mercado en marcha, se supone que en el intercambio farmacéutico minorista (i) todo agente económico es racional, (ii) cada cual busca su beneficio, (iii) todos alcanzan la máxima utilidad ${ }^{16}$. En otros términos, la maximización de

Michael J., What Money can buy. The moral limits of markets, Farrar, Straus and Giroux, New York, 2012, pp. 6-15.

${ }^{14}$ Sobre la cuestión terminológica, y valorando los aspectos teóricos del movimiento liberal económico de las últimas décadas, Ghersı, Enrique, "El mito del neoliberalismo", Estudios Públicos, 95 (invierno 2004), pp. 293-313. En un sentido opuesto, TreANOr, Paul, Neoliberalism: origins, theory, definition, En: http://web.inter.nl.net/users/Paul.Treanor/neoliberalism.html [visitado el 05/02/2013].

${ }^{15}$ La caracterización teórica de la competencia perfecta en VALDÉS PRIETO, Domingo, Libre competencia y monopolio, Editorial Jurídica, Santiago, 2009, pp. 37-39; CIDONCHA, La libertad de empresa, cit. nota n. 1, pp. 130-133.

${ }^{16}$ Los elementos "maximizadores" del mercado en LIPSEY, Richard G., Introducción a la economía positiva, Vicens-Vives, Barcelona, 1989, $3^{\text {a }}$ reimpresión, pp. 207-210, 296-300. 
los beneficios, guía de la toma de decisiones de la industria farmacéutica y las cadenas de farmacias, concurre con la maximización de la utilidad, guía de las decisiones del consumidor de medicamentos.

La interrogante es qué sucede si en la realidad no se cumplen los parámetros precedentes. La respuesta de la ideología del mercado es siempre la misma: dichos parámetros son siempre operantes precisamente porque ocupan en el equilibrio del sistema el mismo papel que en la cosmovisión cristiana tiene la Divina Providencia ${ }^{17}$. Por eso es que la disfunción real o posible del mercado no hace mella en el lugar omnipresente que le asignan, el cual debe ser dejado a sí mismo para solucionar sus propios entuertos. De ahí la inmovilidad de las autoridades legislativas o reguladoras ante las graves deficiencias del mercado. Se resisten a pensar que la maximización de beneficios de unos pueda realizarse perjudicando la utilidad de muchos, como sucede precisamente, según veremos, en el mercado de medicamentos. O más ampliamente, el siempre emergente problema de la desnaturalización de la libre competencia en manos de los más poderosos bajo formas siempre renovadas les parece una accidentalidad transitoria.

Este esquema ideológico tiene una gran incidencia a la hora de desproteger el derecho a la salud en lo que se refiere al acceso a los medicamentos. Pues si el mercado es el más eficiente modelo de asignación de recursos, debe aceptarse, se presupone, la consecuencia de que es el mecanismo más apropiado para la distribución de los medicamentos a la población.

Hay que observar que desde el punto de vista de la protección de la salud como derecho social de carácter constitucional, el padrón puramente económicomecanicista del mercado como eficiente mecanismo de asignación de recursos es una premisa incompleta. Hay varias objeciones que formular al respecto:

a) Desde el ángulo de la ciencia económica, la eficiencia que se le asigna al mercado es una eficiencia teórica, que puede no darse en la realidad ${ }^{18}$. Más aún, el presupuesto ideológico de que el mercado genera un orden espontáneo siempre eficiente porque nace de la libertad, necesita ser probado, contrastándolo siempre con la realidad de los mercados concretos, donde muchas veces la libertad de los grandes forma bloques de poderes privados que inhibe, estruja o tiraniza la libertad de los pequeños.

\footnotetext{
${ }^{17}$ La analogía es de Bruckner: BRUCKNER, Peter, Misère de la prosperité. La religion marchande et ses ennemis: Miseria de la prosperidad. La religión del mercado y sus enemigos (traducción de Amelia Ros), Tusquets, Barcelona, 2003, pp. 128-121.

${ }^{18}$ La eficiencia está bien definida por Stiglitz: "los mercados privados constituyen la mayoría de las veces el mejor mecanismo para mantener la eficiencia económica, para garantizar que se producen los bienes con el menor coste posible y que los que se producen son, de hecho, los que quieren los consumidores". Stiglitz, Joseph, Micoeconomía, Ariel, 1993, p. 197. Pero puede fallar en uno o más de estos supuestos.
} 
b) Desde la perspectiva de la teoría de la regulación jurídica, el derecho sirve de marco para la celebración de los actos jurídicos y contratos, de garantía a los derechos de los agentes económicos, de protección y defensa de la competencia, y de corrección de los denominados "fallos" del mercado. Precisamente, en el ámbito de las garantías, el Estado debe asegurar, directa o indirectamente, la satisfacción de la protección de la salud para toda la población, y con mayor énfasis regulatorio cuando el mercado funciona deficientemente, como en el caso de los medicamentos ${ }^{19}$.

c) Desde el punto de vista ético-jurídico, el mercado es un medio, no un fin $^{20}$. Lo que queda especialmente de manifiesto frente a bienes esenciales del hombre, como los medicamentos. La cuestión no es si el mercado es más o menos eficiente, sino en qué medida la sociedad va a servirse del mercado para proveer a la población de los bienes necesarios que han de estar siempre en condiciones de disposición y accesibilidad.

d) Desde el ángulo de los derechos fundamentales, tratándose de bienes humanos básicos como la salud, el hombre tiene derechos en torno a ella fundado en títulos no exclusivamente utilitarios, como sería su calidad de price takers (en condiciones ideales de mercado) o de precio aceptante (en condiciones reales o frecuentes de mercado). Por derivación, los medicamentos no pueden ni deben ser convertidos en bienes exclusivamente comerciales para el usuario final sin alternativas de accesibilidad al interior de una economía nacional. El riesgo de afectar el derecho a la protección de la salud es alto, particularmente en escenarios donde productores y distribuidores tienen poder sobre el mercado y los "consumidores" son solo "precio-aceptantes". Entonces suele suceder que la racionalidad de la maximización de beneficios de unos vuelve oneroso o impeditivo para parte de la población el acceso a los medicamentos.

e) Desde la misma perspectiva precedente, la mercantilización de los medicamentos para el usuario final, titular del derecho a la protección de la salud,

\footnotetext{
${ }^{19}$ Regular no significa necesariamente "intervenir", pero sí "garantizar". Sobre la ambivalencia del término en la doctrina anglo-americana y en el derecho comunitario europeo, BETANCOR, Andrés, Regulación; mito y derecho. Desmontando el mito para controlar la intervención de los reguladores económicos, Civitas-Thomson Reuters, Navarra, 2010, pp. 31-71. Sobre el concepto de "Estado garante" y la necesidad de regular la "autorregulación" del mercado con técnicas apropiadas, DARNACULleTA, María Mercè, Derecho Administrativo y Autorregulación: la autorregulación regulada, Universitat de Girona, Girona, 2003, pp. 64-87, 521-646. Darnaculleta observa que fruto de la desregularización de los mercados hay un amplio espacio para la llamada "autorregulación". Pero el concepto supone para funcionar (i) la profesionalización efectiva de la empresa, (ii) la expansión de su responsabilidad social y (iii) un marco jurídico apropiado de regulación pública. DARnACULLETA, Derecho Administrativo y Autorregulación, cit. nota n.19, pp. 180-245, 269-272.

${ }^{20}$ En materia de salud, lo reconoce explícitamente la OCDE en lo que se refiere, por ejemplo, a las prestaciones hospitalarias. Organisation for Economic Co-operation and Development (OeCD), Competition Committee, Competition in Hospital Service, 5 de junio de 2012 [DAF/COMP(2012)], pp. 337-338. Dirección Web en Bibliografía Citada.
} 
significa que sólo pueden acceder a ellos quienes tienen poder de compra suficiente. Pero el mercado no funciona para quienes no tienen dicho poder de compra y es dable pensar que hay muchos que estando en tal situación necesitan mantener o recuperar la salud. La protección constitucional de ésta debe asegurar los medicamentos más allá del poder de compra.

f) Desde la óptica del derecho del consumidor, la asimetría jurídica y económica entre productor / distribuidor y consumidor de medicamentos es de destacar, y afecta todo el proceso de distribución de los fármacos. Para los primeros, la salud es ocasión de un acto comercial, parte de una estrategia de venta y de un plan empresarial. Para el segundo, es causa de la celebración de un acto civil, parte de un requerimiento de dispensa y fruto de la necesidad. El productor /distribuidor debe estar al servicio del paciente y no a la inversa.

En nuestro medio, avanzamos lento, probablemente porque la lectura ideológica del mercado convertida en mentalidad nos vela lo esencial: que el mercado que es no funciona como el mercado que debiera ser y sus disfuncionalidades tienden a exasperar sus propias causas. Es lo que evaluamos a continuación.

\section{LA PROTECCIÓN DE LA SALUD Y EL ACCESO A}

LOS MEDICAMENTOS EN EL FUNCIONAMIENTO REAL DEL MERCADO CHILENO

Las reformas a la salud impulsadas por la legislación de los años ochenta establecieron un sistema mixto (privado-público) de salud. En su interior asignaron al mercado un enorme campo de actuación en materia de seguro, financiamiento y prestación de los servicios de salud. Sus impulsores legitimaron dos ideas que habrían de calar hondo en las posteriores décadas, a saber, "la noción de que la salud es un bien que requiere de un pago" y que el lucro "es legítimo y necesario" para obtener mejoras sanitarias sustanciales en beneficio de toda la población ${ }^{21}$.

Sin embargo, los límites de estas ideas eran ya visibles a finales de la década de los noventa, incluso para sus propios defensores, e incidían en el funcionamiento del sistema mixto. Los buenos indicadores globales de salud a nivel nacional, fruto innegable de la competencia inicial y de la innovación, se relativizaron ante la inequidad del subsistema de Isapres hacia categorías enteras de la población y ante las deficiencias de atención, de gestión y de recursos

\footnotetext{
${ }^{21}$ Aedo, Cristián, "Las reformas en la salud en Chile", en Larraín, Felipe y Vergara, Rodrigo (eds.), La transformación económica de Chile, CEP, Santiago, 2001, p. 608. Por "reformas" entiende el sistema implantado por las siguientes normas: el Decreto Ley $N^{\circ} 2.763$ de 1980, el D.F.L. № 1-3.063 de 1980, el Decreto Ley No 3.626 de 1981 y la Ley No 18.933 de 1990. El enfoque del autor es el de la "liberalización económica" como modelo relativamente positivo del progreso de la salud en Chile. En el estudio apenas se menciona la Ley $N^{\circ} 18.469$ y se omite la Ley $N^{\circ} 19.650$, que regulan el ejercicio del derecho constitucional a la protección de la salud.
} 
del sector público ${ }^{22}$. Las reformas posteriores no han logrado subsanar estos fallos ${ }^{23}$. De tal modo que, en lo medular, sigue siendo válida la afirmación de Zúñiga en el sentido de que el sector público "tiende a concentrar a las personas de menores ingresos y mayores riesgos médicos mientras que las ISAPRES atraen a las personas de altos ingresos y bajos riesgos (salvo cuando se trata de mayores de 50 años) $)^{\prime 24}$. Con un condicionamiento adicional: el sistema de salud privado chileno se ubica entre los más caros del mundo.

En efecto, en el mercado local, los costos de hospitalización por día, visita médica de rutina o prestaciones hospitalarias comunes son bastante más caros en comparación con la mayoría de los países desarrollados o los países latinoamericanos ${ }^{25}$. Con el agravante, según datos de la OCDE, asumidos por la Fiscalía Nacional Económica, que los gastos de bolsillo del paciente representa el porcentaje más alto en relación al gasto total en salud. Análoga afirmación se aplica a cirugías y exámenes ${ }^{26}$.

22 Los problemas de gestión y recursos lo reconoce expresamente Aedo, "Las Reformas", cit. nota n. 21, p. 635. En Aedo, "Las Reformas", cit. nota n. 21, pp. 622-635, el autor apunta un cúmulo de problemas: imperfecciones en el mercado de seguros, en el diseño de las cotizaciones, en la coordinación del sector público y privado, en el gasto de salud para el adulto mayor, en la cobertura de las enfermedades catastróficas o crónicas, etc. Las soluciones que propone son todas técnicas, dentro de la lógica del sistema. La discusión sobre el lugar que tiene o que debiera tener el mercado en las prestaciones de salud le parece irrelevante, porque asume la necesaria eficiencia de su mecanismo. La discusión desde el prisma específico de los defectos del sistema de financiamiento sanitario, en ZúÑIGA, Alejandra, "Sistemas sanitarios y reforma Auge en Chile", Acta Bioethica 2007, 13 (2), pp. 241-243.

${ }^{23}$ Zúñiga estima que a pesar de los avances de la reforma AUGE (Ley No 19.966 del 2004), que estableció garantías explícitas de acceso, oportunidad, calidad y costo para un conjunto prioritario de prestaciones de salud, éstas mantienen la inequidad del sistema, puesto que no son ni universales ni igualitarias. ZúÑIGA, Alejandra, "Una teoría de la justicia para el cuidado sanitario: La protección de la salud en la Constitución después de la reforma AUGE", Revista de Derecho, vol. XXIII, N²2, 2010, p. 128. En otro lugar, critica fuertemente "los criterios de racionamiento del utilitarismo sanitario" utilizados en las guías clínicas de las enfermedades garantizadas, ZúÑIGA, Alejandra, "Justicia y racionamiento sanitario en el Plan AUGE: dilemas bioéticos asociados a la distribución de recursos escasos", Acta Bioethica 2011; 17 (1), pp. 77-82. En el mismo sentido, ZúÑIGA, Alejandra, "El derecho a la vida y el derecho a la protección de la salud en la Constitución: una relación necesaria", Estudios Constitucionales, Año 9, № 1, 2011, pp. 54-55. Deficiencias análogas en la atención sanitaria en general y, en particular, en Román, Óscar y MuÑoz, Félix, "Una mirada crítica en torno al plan AUGE: Algunos aspectos generales y valóricos", Revista Médica de Chile, 2008, 136, pp. 1599-1603.

${ }^{24}$ ZúNIIGA, "Sistemas sanitarios y reforma Auge en Chile", cit. nota n. 22, p. 242.

${ }^{25}$ El Mercurio, "Estudio internacional ubica a Chile entre sistemas de salud privados más caros del mundo", Economía y Negocios, 27 de marzo del 2013. El documento original en INTERNATIONAL FEDeration of Health, Plans 2012 Comparative Price Report Variation in Medical and Hospital Prices by Country. Dirección Web en Bibliografía Citada.

${ }^{26}$ La Segunda, "Clínicas privadas en la mira. Cirugías y exámenes en Chile se consideran entre los más caros del mundo", 23 de marzo del 2013. El documento original en FisCalía NACIONAL ECONÓmICA, Mercado de la salud privada en Chile. Estudio solicitado a la Pontificia Universidad Católica de Valparaíso, octubre 2012. Dirección Web en Bibliografía Citada. 
En consecuencia, se puede afirmar grosso modo, que el sistema de salud mixto comporta una dualidad: en lo público es defectivo y en lo privado inequitativo y encarecido.

Esta estructura ha afectado el acceso a los medicamentos. Hay diferencias notables en la distribución de medicamentos al usuario final, según se provean en el sector público o en el privado.

El paciente que por diversas razones no accede a los medicamentos en el marco del Régimen General de Garantías de Salud en los establecimientos asistenciales del Sistema Público (donde subsisten controversias sobre las políticas de calidad y seguridad), debe procurárselos en el mercado (directamente en las farmacias, indirectamente a través de las prestaciones al interior del mercado hospitalario privado).

¿Y cómo se estructura y funciona el mercado de medicamentos en Chile?

A partir de 1980, el legislador entendió que empresas particulares, organizadas dentro del marco de las garantías constitucionales de la libertad económica y la propiedad privada, podían suministrar libremente los fármacos a la población obteniendo a la vez rendimientos económicos. Se sostenía que el interés privado lucrativo armonizaba sin mayor problema con el interés general, por lo que la iniciativa empresarial era capaz de poner a disposición de una población informada y con los incentivos propios de la libre competencia, los medicamentos de calidad, debidamente dispensados, a precios razonables, y con conocimientos adecuado para darles un uso racional.

Por diversos motivos dichas empresas, en los distintos grados de producción, distribución y comercialización de los medicamentos, se centraron cada vez más en sus márgenes de ganancia en desmedro de las exigencias de interés general que impone, por su propia naturaleza, la actividad a la que se dedican, y que se traduce, es importante insistir, en dispensar medicamentos a la población en condiciones de disponibilidad, accesibilidad, calidad garantizada y utilización racional, de acuerdo a los padrones sugeridos por la Organización Mundial de la Salud ${ }^{27}$.

El modo en que se estructura y funciona este mercado, dando mayor o menor énfasis al problema de los medicamentos, ha sido evaluado en tres importantes informes: el informe VASSALLO (2010), del Colegio de Químicos Farmacéuticos de Chile ${ }^{28}$; el informe Pucv (2012), de la Fiscalía Nacional Económica ${ }^{29}$ y

\footnotetext{
${ }^{27}$ Organización Mundial de la Salud (OMS), Perspectivas políticas de la OMS sobre medicamentos, Documento 8: Acceso equitativo a los medicamentos esenciales: un marco para la acción colectiva, Ginebra, marzo 2004, p. 1, En: http://archives.who.int/tbs/ndp/s4964s.pdf [visitado el 07/01/2013].

${ }^{28}$ VaSSALLO, Carlos, El mercado de medicamentos en Chile: caracterización y recomendaciones para la regulación económica. Informe solicitado por el Colegio de Químicos Farmacéuticos de Chile, junio 2010. Dirección Web en Bibliografía Citada.

${ }^{29}$ Fiscalía Nacional Económica, Mercado de la salud privada en Chile, cit. nota n. 26. El documento analiza en detalle las deficiencias estructurales y funcionales del mercado de la salud privada, particular-
} 
el informe Ims Health (2013) del Ministerio de Economía ${ }^{30}$. Desde un punto de vista puramente económico, todos coinciden en la disfuncionalidad del mercado: la maximización de los beneficios de la industria farmacéutica y las grandes cadenas de farmacias no coincide con la maximización de la utilidad del consumidor, puesto que éste tiene que sufragar precios desmedidos en los medicamentos y en las prestaciones del sistema en general, con alta incidencia promedio porcentual para el ingreso familiar, especialmente tratándose de las clases medias.

Si se cruzan los datos de los reportes precedentes, más las informaciones fidedignas de otros documentos complementarios, se llega a la siguiente radiografía de los problemas del mercado de medicamentos chileno:

1) Graves problemas de concentración económica y de ausencia de competencia suficiente:

i) En el mercado de provisión de medicamentos, las corporaciones que los producen o importan para comercializarlos en Chile concentran gran parte del mercado, con tendencias al oligopolio con diferenciación de productos. A este nivel, se constata una competencia reducida entre los grandes laboratorios, que a su vez poseen la mayoría de los registros farmacéuticos ${ }^{31}$.

(ii) En el mercado de distribución minorista, las tres grandes cadenas de farmacias concentran el 95\% de las ventas del país, ostentando un relevante poder de mercado ${ }^{32}$. Hay barreras de entrada a la venta minorista de medicamentos, con costos hundidos casi imposibles de franquear ${ }^{33}$.

(iii) Integración vertical ascendente: las tres grandes cadenas de farmacias controlan laboratorios y distribuidoras de medicamentos ${ }^{34}$, generando el incentivo de favorecer los propios productos, con todas sus consecuencias perversas

\footnotetext{
mente en lo que se refiere a la estructura de la propiedad de las Isapres (y sus vínculos con laboratorios y centros hospitalarios), y a los mercados de aseguramiento y provisión de la salud. FISCALÍA NACIONAL ECONÓmicA, Mercado de la salud privada en Chile, cit. nota n. 26, pp. 37-178.

${ }^{30}$ Ministerio de EConomía, Fomento y Turismo. División de Estudios, El mercado de medicamentos en Chile, estudio basado en la información proporcionada por IMS Health, el Ministerio de Salud y el Instituto de Salud Pública, abril 2013, 18 pp. Dirección Web en Bibliografía Citada.

${ }^{31}$ Vassallo, El mercado de medicamentos en Chile, cit. nota n. 28, pp. 5, 16-24, 56-57.

32 Ministerio de Economía, Fomento y Turismo. División de Estudios, El mercado de medicamentos en Chile, cit. nota n. 30, p. 3.

${ }^{33}$ VASSALLO, El mercado de medicamentos en Chile, cit. nota n. 28, p. 6.

${ }^{34}$ VASSAlLO, El mercado de medicamentos en Chile, cit. nota n. 28, pp. 12, 25, 86. Paralelamente existe integración vertical descendente entre Isapres y prestadores de salud (especialmente clínicas privadas), y éstos con fondos de inversión. Los últimos, a su vez, invierten en laboratorios. Los detalles en Fiscalía Nacional ECOnÓmica, Mercado de la salud privada en Chile, cit. nota n. 26, pp. 37-71. Su valoración en Ibíd. pp. 173-177.
} 
(comisiones de venta, captura de las prescripciones médicas por la vía de beneficios suplementarios, sustitución de receta médica, etc.).

(iv) Las tres grandes cadenas de farmacias comparten desde hace años posiciones de dominio en la comercialización de medicamentos, con frecuente interacción entre ellos para mejorar sus márgenes de rentabilidad.

Lo anterior ha afectado la accesibilidad de los medicamentos:

(a) La baja elasticidad en la demanda de remedios éticos, hace posible el incremento arbitrario de precios sin que pueda disminuir sustancialmente la demanda ${ }^{35}$.

(b) El año 2012, las tres grandes cadenas fueron condenadas por el Tribunal de Defensa de la Libre Competencia y la Corte Suprema por fijar concertadamente, con la ayuda de los laboratorios proveedores de los productos, el alza del precio de venta al público de 206 medicamentos, de casi nula sustitución. Se trataba en gran parte de remedios éticos de enfermedades crónicas y agudas ${ }^{36}$. El año 1995 ya habían sido objeto de una condena análoga ${ }^{37}$.

2) Graves problemas de atención farmacéutica: la lógica de la utilidad y del aumento de los márgenes de ganancia se ha convertido en un criterio primordial para proveer de medicamentos a los chilenos, con un cúmulo de efectos distorsionantes para su accesibilidad y disponibilidad:

(i) Las farmacias adoptan el formato "drugstore" y el modelo de negocios "retail", en convenio con las principales casas comerciales del país, para que los pacientes devenidos en clientes obtengan crédito, y aumente la rentabilidad del negocio ${ }^{38}$.

(ii) Detrimento del rol de dispensación del químico farmacéutico y protagonismo exclusivista de la gestión y estrategia de venta.

\footnotetext{
${ }^{35}$ VASSAllo, El mercado de medicamentos en Chile, cit. nota n. 28, pp. 6, 8, 57. Los medicamentos éticos son los que se venden bajo receta médica.

${ }^{36}$ Fiscalía Nacional Económica con Farmacias Ahumada S.A., Farmacias Cruz Verde S.A. y Farmacias SalcoBrand S.A., Corte Suprema, Requerimiento por Conductas Colusorias, 7 de septiembre del 2012, considerandos decimotercero, septuagésimo sexto, septuagésimo séptimo y octogésimo octavo, En: http://suprema.poderjudicial.cl/SITSUPPORWEB/InicioAplicacion.do [visitado el 04/03/2013]. Fiscalía Nacional Económica con Farmacias Ahumada S.A., Farmacias Cruz Verde S.A. y Farmacias Salco Brand S.A., Tribunal de Defensa de la Libre Competencia, Requerimiento por conductas Colusorias, 31 de enero de 2012, En: http://www.tdlc.cl/Portal.Base/Web/VerContenido.aspx?ID=1829 [visitado el 04/03/2013].

37 Farmacias Ahumada, Farmacias Cruz Verde, Comercial Salco y Farmacias Brand, Comisión Resolutiva Antimonopolio, condena por conductas de colusión, 16 de mayo de 1995, En: http://www. fne.gob.cl/jurisprudencia-en-libre-competencia/decisiones-comisiones-antimonopolio/ [visitado el 04/03/2013].

${ }^{38}$ CASTILLO, Leonardo, Colusión en mercados relevantes: un aporte a la discusión, Flacso-Chile, Santiago, 2009, pp. 5-6. Dirección Web en Bibliografía Citada.
} 
(iii) Millonarias estrategias de marketing para fidelizar a los clientes, cuyos costos pagan los mismos clientes.

(iv) Ejecutivos especialmente contratados para obtener mayor utilidad de los medicamentos (category manager).

(v) El precio de los remedios se encarece por el pago a diversos agentes que, ocupando diferentes roles, participan en las distintas etapas del intercambio comercial.

(vi) Incentivos económicos para la prescripción y venta de determinados fármacos. Los incentivos para la prescripción son utilizados generalmente por los laboratorios que fabrican o compran el principio activo desarrollado por el laboratorio de investigación, y lo comercializan. Los incentivos para la venta son adoptados por las grandes cadenas de farmacias con el objeto de comprometer en la estrategia comercial al personal que expende los medicamentos ${ }^{39}$.

3) Graves problemas de Derecho del consumidor: anómalas condiciones de comercialización que perjudican el estado de accesibilidad, disponibilidad y uso racional de los medicamentos:

(i) Ausencia de información relevante para conocer las razones del alto valor o del incremento del precio final de los remedios, lo que es especialmente grave tratándose de medicamentos éticos ${ }^{40}$.

(ii) Falta de transparencia en la información sobre el precio, calidad y efectividad del fármaco en correlación con sus sustitutos disponibles.

(iii) La carga de la búsqueda del medicamento más accesible se traslada al consumidor cuando la farmacia no cumple con su obligación (hasta el 2011 inexistente) de dar información visible sobre sus precios ${ }^{41}$.

\footnotetext{
${ }^{39}$ Las prácticas (ii), (iii), (iv), (v) y (vi), en las que inciden los problemas de estructura y funcionamiento del mercado de medicamentos, son reconocidas por las autoridades de salud y los distintos actores involucrados. Senado de la República, Comisión de Salud, Primer Informe, 15 de julio 2010 sobre reforma del Código Sanitario (Boletines Noㅇ. 6.523-11, 6.037-11 y 6.331-11, refundidos), pp. 6-46. En cuanto al ánimo exclusivista de lucro, vid. deposición reproducida en Fiscalía Nacional Económica con Farmacias Ahumada S.A., Farmacias Cruz Verde S.A. y Farmacias Salco Brand S.A., Corte Suprema, Requerimiento por Conductas Colusorias, 7 de septiembre del 2012, considerando vigésimo sexto, № 3, letra c., En: http://suprema.poderjudicial.cl/SITSUPPORWEB/InicioAplicacion.do [visitado el 04/03/2013].

${ }^{40}$ Un ejemplo, entre otros. El inhalador presurizado Salbutamol, que la Central Nacional de Abastecimiento, CenABAST, vendía a \$ 690, en las cadenas de farmacias se ofrecía a \$ 6.010, promedio. El inhalador Budesonida, que en CENABAST estaba a \$1.664, en las cadenas se expedía a \$16.103, promedio. El Salmeterol que CenABASt ofrecía a \$ 4.119, en las grandes cadenas ascendía a \$26.875, promedio. CASTILLO, Colusión en mercados relevantes: un aporte a la discusión Castillo, cit. nota n. 38, pp. 4-5. Los datos de los dos primeros insumos son reproducidos en: Fiscalía Nacional Económica con Farmacias Ahumada S.A., Farmacias Cruz Verde S.A. y Farmacias Salco Brand S.A., Corte Suprema, Requerimiento por Conductas Colusorias, 7 de septiembre del 2012, considerando septuagésimo séptimo, En: http:// suprema.poderjudicial.cl/SITSUPPORWEB/InicioAplicacion.do [visitado el 04/03/2013].

${ }^{41}$ MuÑoz, Francisco Javier, Dispersión de Precios y Costos de Búsqueda en el Mercado Farmacéutico Chileno, Instituto de Economía de la Pontificia Universidad Católica, Santiago, 2011, p. 38. Ministerıo
} 
(iv) Práctica de conservación de los datos sensibles de los pacientes extraídos de las recetas médicas para técnicas de mercadeo.

(v) En razón de los incentivos económicos de los agentes de venta, de las estrategias de publicidad, y de las asimetrías de información, el consumidor, carente de conocimientos especializados en componentes activos y en porcentajes de concentración o pureza de los medicamentos que usa, queda expuesto a lo que el vendedor le pueda recomendar de acuerdo con el criterio de utilidad comercial $^{42}$.

(vi) Los fármacos en las clínicas también son un problema. En precios de insumos y medicamentos en hospitalización, se han detectado diferencias de hasta un $345 \%$, y, en general, el usuario no cuenta con un mecanismo de acceso fácil y expedito para informarse ${ }^{43}$.

El denominador común de las falencias precedentes (1-2-3) es la afectación del acceso a los medicamentos de la población por la vía del encarecimiento sistemático de los precios, tendencia comprobada desde 1999. Con el alza de precios se benefician no sólo las cadenas de farmacias sino también los laboratorios que operan en nuestro país ${ }^{44}$.

En el período 2002-2008, los precios se incrementaron nominalmente en un $68 \%$ para los medicamentos de marca, un $46 \%$ para los similares y un $32 \%$ para los genéricos, con una evolución incremental mayor al IPC y al índice del sector salud.

Las estadísticas de la década 1999-2008 indican que: (a) el consumo anual de medicamentos se ha mantenido (en unidades), pero su costo asociado se ha incrementado en aproximadamente el doble, y (b) en todos los quintiles, el gasto en medicamentos corresponde a un 40 a $50 \%$ promedio del gasto dedicado a salud de los presupuestos familiares ${ }^{45}$.

DE SALUD DE ChILE, Reglamento sobre información de precio de productos farmacéuticos y productos en general al interior de farmacias y almacenes farmacéuticos, Decreto $N^{\circ} 142$ del 10 de diciembre del 2009. Vigencia desde el 1 de febrero del 2011.

${ }^{42}$ El Presidente de la Federación Nacional de Trabajadores de Farmacias de Chile declaró que en algunas cadenas de farmacias alrededor del $80 \%$ de la remuneración mensual de un trabajador corresponde a comisiones por venta de determinados fármacos. SenAdo de la República, Comisión de SAlud, Segundo Informe, 3 de enero 2012 sobre reforma del Código Sanitario (Boletines $\mathrm{N}^{\circ} \mathrm{s}$. 6.523-11, 6.037-11 y 6.331-11, refundidos), p. 20.

${ }^{43}$ Servicio Nacional del Consumidor (Sernac), Estudio de precios de prestaciones médicas del 17 de octubre del 2011, sobre la base de 64 prestaciones, insumos y medicamentos vigentes al 24 de agosto de 2011, en dieciséis instituciones de la región Metropolitana. Dirección Web en Bibliografía Citada.

${ }^{44}$ Ministerio de Salud, Comisión de Reforma de la Salud, Minuta Política Nacional de Medicamentos en el contexto de la Reforma de Salud, Santiago, abril 2004, p. 2. En: http://ciperchile.cl/wp-content/ uploads/estudio-comision-reforma-de-la-salud.pdf [visitado el 07/02/2013].

45 Ministerio de Salud, Subsecretaría de Salud Pública, Departamento de Políticas farmacéuticas y profesiones MÉDICAS, Manual de Selección de Medicamentos: metodología para la selección de medicamentos del 
Hay otras estadísticas sintomáticas, si bien incompletas en cuanto al tiempo o factores medidos. Investigaciones encargadas por el MINSAL Ilegaron a la conclusión que durante el quinquenio 1999-2003 el costo de la vida (IPC) en Chile aumentó en un 14,07\%, mientras el precio promedio de los medicamentos lo hizo en un 63,46\%. Mientras tanto, entre los años 1995-2002, la rentabilidad promedio de las cadenas de farmacias aumentó sistemáticamente de un 19\% a un $30 \%{ }^{46}$. Otros estudios han acreditado que en nuestro país el precio de los fármacos es proporcionalmente más alto que el ingreso promedio, a diferencia de los países desarrollados ${ }^{47}$. Asimismo, según consta en la sentencia de la Corte Suprema ya citada, las tres grandes cadenas de farmacias alzaron sus precios entre diciembre de 2007 y abril del 2008 en un promedio de incremento de un $48 \%$, llegando en no pocos casos a más del $100 \%$, en circunstancias que el precio de compra no sufrió variación superior al $1 \%{ }^{48}$.

Para el período 2008-2012, el Informe Ims Health (2013) también destaca la tendencia al alza en los precios, tanto en los fármacos de venta directa como en los sujetos a receta médica. De hecho, el precio promedio de los medicamentos se ha elevado un 23,1\% en los últimos cinco años. En el mismo período los ingresos de las farmacias se han incrementado un 34,1\%: en el 2008 las ventas fueron por \$ 545.446 millones, en 2012 por \$ 731.424 millones. Del total, los mayores ingresos se obtienen porcentualmente por la venta de los medicamentos más caros: un 41,1\% por concepto de medicamentos de marca y un $46,5 \%$ por venta de medicamentos de similares. Durante el mismo período, ha disminuido la venta de los sustitutos de los remedios caros: entre 2008 y 2012 las unidades vendidas de genéricos decrecieron en un $14,6 \%$ en las tres principales cadenas farmacéuticas ${ }^{49}$.

Relacionado con la accesibilidad, hay también problemas de disponibilidad. Dado que existen importantes diferencias de precios entre productos de marca, similares y genéricos, las cadenas de farmacias prefieren poner a disposición los medicamentos de marca y no sus sustitutos bioequivalentes, pues así obtienen mejores ganancias ${ }^{50}$.

Formulario Nacional y arsenales farmacoterapéuticos de los establecimientos de salud, 2010, pp. 1517. Dirección Web en Bibliografía Citada.

46 Ministerio de Salud. Minuta, cit. nota n. 44, pp. 2-3.

47 Danzon, Patricia M. y Furukawa, Michael F., Prices And Availability Of Pharmaceuticals: Evidence From Nine Countries, Health Affairs, 2005, p. 527. Dirección Web en Bibliografía Citada.

${ }^{48} \mathrm{Un}$ análisis general de los precios en el mercado y sus determinantes, así como de los precios de venta del Estado, en VASSAlLo, Carlos, El mercado de medicamentos en Chile, cit. nota n. 28, pp. 31-49.

${ }^{49}$ Ministerio de ECOnomía, El mercado de medicamentos en Chile, cit. nota n. 30, pp. 2, 4-11.

${ }^{50}$ Servicio Nacional del Consumidor (Sernac), Estudio de precios de medicamentos bioequivalentes del 29 de octubre del 2012. Constata que en septiembre 2012 (a) las tres grandes cadenas de farmacias comercializan sólo un $23 \%$ de los bioequivalentes disponibles, y (b) el precio de los bioequivalentes 
Asimismo, no existe correlación entre el número de farmacias, ubicación geográfica y disponibilidad de los medicamentos. Las cadenas instalan locales donde pueden obtener mayores beneficios económicos, por lo que existen comunas donde no hay farmacias, y amplias zonas, densamente pobladas, con escasos locales ${ }^{51}$.

Las cifras precedentes pueden ser leídas de diversa manera. Sin embargo, de ellas se deduce una conclusión indiscutible: que el mercado de medicamentos no funciona como la teoría económica, el derecho de defensa de la competencia y el derecho de protección al consumidor nos dicen que debiera funcionar. El mercado real de medicamentos no coincide con el mercado que debiera ser.

Para que se mida el calado de esta conclusión se han de volver a mirar algunos de sus detalles, pero ahora con un cariz comparativo desde la propia lógica del mercado:

a) En cuanto a la estructura del mercado de medicamentos:

- La integración vertical entre distribuidores (farmacias) y productores / importadores (laboratorios), tal como está operando, perjudica la competencia suficiente en la oferta de medicamentos en sus distintos niveles ${ }^{52}$.

- El fenómeno de concentración oligopólica de las tres grandes cadenas de farmacias impone barreras de entrada de tal entidad que, en concreto, vulnera actual o potencialmente la libertad de acceso al mercado de las pequeñas y medianas empresas y la libertad de permanencia en el mercado de las Ilamadas farmacias independientes. Sin la libertad de las pequeñas y medianas empresas la libre competencia es una ilusión.

- La integración y concentración precedentes otorgan a las cadenas de farmacias un poder determinante para manejar los precios, en especial tratándose de situaciones de demanda con poca elasticidad, como es el caso del mercado de medicamentos éticos. Lo cual altera la imagen maestra del mercado donde los precios los fija el libre juego de demandantes y oferentes al interior de un mecanismo que se supone neutro. En la práctica, los demandantes quedan maquinalmente en la condición de precio aceptantes pasivos.

b) En cuanto al funcionamiento del mercado:

- La integración y concentración aludida tolera o permite a una de las partes - productores y distribuidores- marginar utilidades sostenidas en el tiempo,

es hasta casi 20 veces más económico que su medicamento de referencia. Dirección Web en Bibliografía Citada.

${ }^{51}$ VASSALLO, El mercado, cit. nota n. 28, pp. 26-27.

52 Hablamos de competencia suficiente y no de competencia perfecta, paradigma hoy discutido. Cidoncha, La libertad de empresa, cit. nota n. 1, pp. 128-138. A nivel de prestadores de salud, la integración vertical comporta la generación de nuevas barreras de entrada y la suavización de la competencia por calidad. Fiscalía Nacional Económica, Mercado de la salud privada en Chile, cit. nota n. 26 , pp. 174-175. 
exista o no colusión entre ellos. Laboratorios y cadenas de farmacias quedan en condiciones de maximizar siempre sus beneficios a cargo del resto de los agentes económicos, los consumidores, que se ven perjudicados siempre en la maximización de su utilidad (salvo en situaciones de "guerra de precios"). Lo que atenta contra una de las funciones esenciales del mercado: la eficacia en la asignación de los recursos.

- La información sobre los productos del mercado de medicamentos es por naturaleza asimétrica: para conocer la forma de medicación y la calidad de los fármacos e insumos médicos se requiere de un conjunto de conocimientos técnicos que normalmente están fuera del alcance del consumidor medio. La elección de mercado del demandante depende en gran parte de terceros: del médico prescriptor o del farmacéutico. Pero si dicha elección depende del agente de venta, como es recurrente en Chile, y éste es impulsado primordialmente por el afán de lucro, se distorsiona gravemente las condiciones de racionalidad en la libre elección del demandante. Racionalidad que, se supone, es una de las base de la economía de mercado.

- Entre los agentes económicos del mercado, los consumidores (que son los afectados) son los únicos que no conocen a ciencia cierta el motivo del alza sostenida de los precios de los medicamentos. Ni tampoco poseen directamente los medios para comprobar la información genérica que al respecto puedan darle productores y distribuidores. Hay informaciones parciales sobre la notable desproporción entre determinados precios que ofrece CENABAST y los que ofrecen las cadenas de farmacias por un mismo producto. Pero las preguntas fundamentales quedan sin respuesta: ¿qué porcentaje del incremento de utilidades de los últimos años corresponde al mayor volumen de ventas y cuál al mayor margen de ganancia por unidad vendida? ¿Qué porcentaje del alza sostenida de los precios se debe al aumento de utilidad neta, cuál a la inversión en técnicas de mercadeo y publicidad, o al simple crecimiento de la empresa para maximizar sus ganancias? El Estado parece no tener herramientas para transparentar esta opacidad. Sólo se sabe una cosa: que lo que paga el demandante por el producto no es sólo el producto: es una suma, para él aleatoria, de condiciones de venta, sobre las cuales él no tiene posibilidades de optar. Fruto característico de los mercados oligopólicos sin garantías para el consumidor ${ }^{53}$.

\footnotetext{
${ }^{53}$ En Europa, v. gr., también hay mercados oligopólicos, pero con ciertas garantías para el consumidor en cuanto al precio y a la información sobre los medicamentos. En cuanto a esto último, por ejemplo, se puede conocer fácilmente cuál es el precio de venta de laboratorio de los medicamentos, cuál es el margen de utilidad del mayorista y el margen de utilidad de la farmacia minorista. ANTOÑANZAS, Fernando et al., "Los medicamentos en la Unión Europea: el tándem comercio-salud", Gaceta Sanitaria, 2005, № 19 (2) p. 156. Los datos actualizados, por ejemplo, para España, se pueden encontrar en la página web de Farmaindustria.es. Lo mismo dígase del resto de los países europeos, a nivel nacional o comunitario. En nuestro país, Farmaindustria sólo tiene una página web en construcción: www. farmaindustria.cl [visitada el 23/05/2013].
} 
"Protección de la salud, acceso a los medicamentos y deficiencias del mercado. Hacia un derecho social plurivalente en el marco de una economía social de mercado"

La conclusión se impone una vez más: el mercado de medicamentos en Chile es deficitario, puesto que distorsiona las reglas del libre mecanismo de la oferta y la demanda. Hay una imposición, por una de las partes, de las condiciones objetivas (precios, a veces cantidades) del intercambio.

Es importante insistir en esta conclusión por dos razones. Primero, a fin de evitar que la ideología de mercado nuble nuestra visión, sustituyendo las condiciones defectivas del mercado de medicamentos por unas ideales, inexistentes, derivadas de una concepción puramente utópica. Segundo, porque el Estado tiene el deber de garantizar el acceso a los medicamentos, en cuanto derecho social, en la misma medida en que el mercado se muestre defectivo por estructura o funcionamiento.

Para enfrentar estas deficiencias dentro de la lógica del mercado se han planteado propuestas de regulación concretas desde el punto de vista del derecho público económico. Al respecto, si bien objetamos la parcialidad de la solución adoptada por el Informe Ims HeAlth $(2013)^{54}$, estamos de acuerdo en las líneas gruesas con las soluciones normativas del Informe VASSAllo $(2010)^{55}$ y del Informe Pucv $(2012)^{56}$.

\footnotetext{
${ }^{54}$ Como única solución, el Informe Ims HeALth propone extender la comercialización de medicamentos de venta directa a los establecimientos comerciales. Estima que, de acuerdo a las reglas de la competencia, se ampliará la cobertura de la oferta y, en consecuencia, se reducirán los precios en dicho segmento de fármacos. MinISTERIO DE ECONOMÍA, El mercado de medicamentos en Chile, cit. nota n. 30, pp. 13-14. A nuestro juicio, este es un ejemplo característico de cómo la ideología del mercado paraliza la posibilidad de una solución inteligible e integral a las deficiencias reales que sufre éste, particularmente agudas tratándose de aquellos medicamentos que precisamente no son de venta directa, y que, por tanto, no recibirían ningún arreglo.

${ }^{55}$ Analizando el mercado de medicamentos en su conjunto, Vassallo propone una regulación sistemática, que supone implementar medidas concretas en dos dimensiones: (a) sobre el mercado, normas de regulación técnica, económica y de vigilancia a cargo de órganos contralores ya existentes, así como estrategias de información a pacientes, prescriptores y dispensadores; b) sobre el Estado, deberes de provisión mínima en la selección, compra, distribución y utilización de medicamentos. Todo lo cual supone, para su sostenibilidad, la transformación de CENABAST en empresa pública. VASSALLO, EI mercado, cit. nota n. 28, pp. 91-125. En su estudio es notable el equilibrio entre el papel asignado al mercado (libre y suficientemente competitivo) y la función que atribuye al Estado como proveedor de medicamentos, que podría asimilarse, con correcciones, al concepto de "Estado garante" del derecho comunitario europeo. En este sentido, hay que observar que las medidas propuestas suponen el uso de técnicas conforme al mercado y están destinadas en su conjunto a compensar socialmente sus deficiencias en el ámbito del acceso y de la competencia de los medicamentos en todos sus grados. Estimamos, sin embargo, que sólo indirecta y eventualmente quedaría solucionado el problema gravitante del alza sistemática de los precios.

${ }^{56}$ El Informe Pucv se enfoca en el mercado de aseguramiento y provisión de la salud, que transversalmente toca el acceso a los medicamentos, como componentes integrales de las prestaciones de salud otorgadas directamente por las clínicas privadas y aseguradas por las Isapres. Las propuestas de regulación son todas conforme al mercado y buscan disminuir sus deficiencias tanto respecto de los planes de salud (reducción de la asimetría de información respecto de su calidad y valor, control del alza de precios mediante el IPC de la salud, mengua de la cautividad al interior del sistema, etc.)
} 
Empero, en sede de derechos sociales, se requiere de un enfoque distinto, aunque complementario, que encuentra su matriz no en la lógica del mercado sino en la noción de protección de la salud como derecho fundamental. Porque una vez constatadas las deficiencias del mercado, se impone la necesidad de superarlas más allá de la ideología economicista, especialmente en razón del derecho a la protección de la salud en el marco de una economía social de mercado. Es lo que haremos a continuación.

\section{El marco teÓrico del aCCeso a los \\ MEDICAMENTOS ANTE LAS DEFICIENCIAS DEL MERCADO (I): \\ LA PROTECCIÓN DE LA SALUD COMO DERECHO SOCIAL PLURIVALENTE}

La Constitución de 1980 llamó a la empresa privada a colaborar en los servicios sociales básicos como la salud, en una época en que se constataba la ineficiencia y desfinanciamiento del Estado para lograr tales objetivos. Toda la estructura normativa del artículo $19 \mathrm{~N}^{\circ} 9$ que garantiza el derecho a la protección de la salud se funda precisamente en la idea de que la iniciativa privada puede dispensar estos servicios, correspondiéndole al Estado el deber preferente de garantizar el libre e igualitario acceso a las acciones de promoción, protección y recuperación de la salud, así como su ejecución, coordinación y control.

Sin embargo, como sabemos, la realidad de la salud en Chile se ha alejado de la axiología del constituyente. Se suponía que los privados, en un contexto de sana y libre competencia, ofrecerían un acceso a la salud con mejores servicios a precios razonables a todos los chilenos. Y que el Estado, a su vez, inyectaría recursos en un sistema de salud público universal y moderno, gestionado con prestancia. Pero esto no ocurrió en distinto grado.

De ahí que en los últimos años haya surgido la necesidad de replantear en nuestro país el valor de la protección de la salud en cuanto derecho social. Pero el debate sigue abierto, al menos a nivel conceptual. Para unos, la protección de la salud no podría ser un derecho social, dado que el constituyente, influido por una idea en exceso liberal del Estado, pensó en él como un derecho puramente negativo, de no intervención y no como un derecho afirmativo a exigir

como de sus prestadores (superación de la falta de transparencia en los indicadores de precio y de calidad por servicio y gestación de mecanismos de elección realmente libres). Hay también recomendaciones indicativas sobre la estructura de la propiedad. Fiscalía NACIONAL ECONÓmicA, Mercado de la salud privada en Chile, cit. nota n. 26, pp. 179-185. Es de lamentar que un documento tan fundado se limite a proponer técnicas conforme al mercado chileno en particular, y no al mercado en general. Dado que muchos de los déficits del mercado chileno son estructurales, se puede prever, si no nos equivocamos, que dichas técnicas, de aplicarse, servirán sólo para aminorar los problemas, pero no para solucionarlos. 
prestaciones determinadas a los Servicios Públicos ${ }^{57}$. Para otros, la Constitución sí consagraría un auténtico derecho social puesto que el Estado tiene, por mandato jurídico, el deber de asegurar a toda la población condiciones mínimas de salud para llevar una vida digna. Lo que, a su vez, también se derivaría de los principios de igualdad de oportunidades y de solidaridad, y del artículo 12 del pacto de los Derechos Sociales, Económicos y Culturales, entre otros ${ }^{58}$.

Pesa en esta controversia la imprecisión del concepto jurídico de salud. Y los variados significados de la noción de derecho social, sobre el cual la doctrina comparada desborda ríos de tinta ${ }^{59}$.

Reduciendo la cuestión a la doctrina chilena, no existe acuerdo sobre la naturaleza y alcance del derecho en comento. Al respecto, se denotan diversas concepciones, que podemos clasificar del modo siguiente:

i) La protección de la salud como derecho social integral. Se trata de la conocida tesis, notablemente argumentada, que viene sosteniendo el Prof. Nogueira Alcalá, como exigencia concurrente de tres instituciones: el Estado social y democrático de derecho, la dignidad humana y el bloque constitucional de derechos fundamentales del "constitucionalismo latinoamericano".

Nogueira sostiene que los derechos sociales generan diversas cotas de obligación para el Estado, las que, en su conjunto, permiten atribuirle fuerza normativa directa y aplicabilidad inmediata. Entre dichas obligaciones resaltan

\footnotetext{
${ }^{57}$ VÁsQueZ, José Ignacio, "El déficit garantístico del artículo 19 № 9 de la Constitución", en Actas XXXIV Jornadas de Derecho Público, LexisNexis, Santiago, 2005, p. 396; SuÁrez, Christian, "Los derechos económicos y sociales en la Constitución Chilena y los límites de la jurisprudencia", en NogueirA, Humberto (coor.), Dogmática y aplicación de los derechos sociales, Librotecnia, Santiago, 2010, p. 111; Henríquez, Miriam, "El derecho a la protección de la salud", en Aguilar, Gonzalo (coor.), Derechos económicos, sociales y culturales en el orden constitucional chileno, Librotecnia, Santiago, 2012, pp. 436 y 448; ZúNIIGA, Francisco, "Jurisprudencia del Tribunal Constitucional acerca de Derechos Económicos, Sociales y Culturales", Revista de Derecho del Consejo de Defensa del Estado, № 20, 2008, p. 85. Una revisión histórica en esta línea, Couso, Javier y ReYEs, Mauricio, "Notas acerca del origen y trayectoria del derecho constitucional a la protección a la salud en Chile", Revista de Derecho de la Universidad católica del Norte, 2009, № 2, pp. 14-23.

${ }^{58}$ BuLNES, Luz, "El derecho a la protección de la salud en la Constitución de 1980", Gaceta Jurídica 295 (1), 2005, pp. 27-29; Silva Bascuñán, Alejandro, Tratado de Derecho Constitucional. De los derechos y deberes constitucionales, Editorial Jurídica de Chile, Santiago, Tomo XII, 2008, p. 130; NogueirA, Humberto, Derechos Fundamentales y garantías constitucionales. Los derechos sociales fundamentales, Librotecnia, Santiago, 2009, p. 108; CEA, José Luis, Derecho Constitucional Chileno, Ediciones Universidad Católica, Santiago, Tomo II, 2012, p. 333; NAnCuAnTe, Ulises y Sotomayor, Roberto, EI derecho de la salud, ConoSur, Santiago, 2001, pp. 24-25; Bronfman, Alan, Martínez, José Ignacio, NúÑez, Manuel, Constitución Política comentada. Parte Dogmática. Doctrina y Jurisprudencia, Abeledo Perrot, Santiago, 2012, p. 225, con un análisis problemático de la jurisprudencia de la Corte Suprema y del Tribunal Constitucional, pp. 229-239.

${ }^{59}$ Restringiendo el problema solo al derecho social a la salud, Cruz Pacero enumera nada menos que catorce significados. Cruz PARCERO, Juan Antonio, El lenguaje de los derechos. Ensayo para una teoría estructural de los derechos, Trotta, Madrid, 2007, pp. 78-79.
} 
las de respeto, protección, promoción, garantía o satisfacción, especialmente eficaces tratándose del derecho a la salud, que por vía legislativa y especialmente judicial, puede volverse operativo con características de universalidad, equidad y calidad en distintos niveles: como políticas de salud, facultades de prestación, derecho al mínimo vital o derecho a elegir el sistema de salud ${ }^{60}$.

En este cuadro, los derechos sociales serían justiciables al menos en cuanto a su contenido mínimo, sobre la base de una relación jurídica determinada. Lo "mínimo" queda delimitado por el aseguramiento de la existencia material del ser humano ${ }^{61}$. Si interpretamos bien el pensamiento del autor, suponemos que más allá de este contenido mínimo existe la obligación de realización progresiva por parte del Estado. Realización que no queda al albur de la voluntad política futura, sino que le es exigible jurídicamente.

El aporte del Prof. Nogueira a la doctrina chilena es esencial, pues abre el horizonte hacia una concepción plurivalente (normas, políticas públicas, facultades) de los derechos sociales, que nosotros seguiremos en muchos de sus aspectos. Pero hay un punto problemático a nivel de fundamentación y es la integración del "constitucionalismo latinoamericano". La tesis de la supremacía del sistema interamericano de derechos humanos, que en la práctica otorga una amplísima competencia en su delimitación a los miembros de la Corte IDH, nos parece peligrosa ${ }^{62}$.

En este esquema, es interesante la postura del Prof. Hernández Emparanza. Si bien parte de la base que la Constitución chilena otorga escaso contenido sustantivo a los derechos sociales, observa que los tribunales chilenos han expandido su contenido con una jurisprudencia de carácter tutelar. Por lo que, aun cuando no integren como corresponde el sistema interamericano de

\footnotetext{
${ }^{60}$ Nogueira, Humberto, "Los derechos económicos, sociales y culturales como derechos fundamentales efectivos en el constitucionalismo democrático latinoamericano", Estudios Constitucionales, Año 7, № 2, 2009, pp. 143-184. Más ampliamente, NogueirA, Derechos fundamentales, cit. nota n. 58.

${ }^{61}$ Nogueira, "Los derechos económicos, sociales y culturales", cit. nota n. 60, pp. 184-199. Sobre la justiciabilidad y la eficacia inmediata, Nogueira, Humberto, "La protección de los derechos sociales como derechos fundamentales de eficacia inmediata y justiciables en jurisdicción constitucional: la sentencia del Tribunal Constitucional Rol № 1710-2010-INC, del 6 de agosto del 2010, sobre la inconstitucionalidad del artículo 38 Ter de la Ley de Isapres", Estudios Constitucionales, Año 8, № 2, 2010, pp. 763-798.

${ }^{62}$ Ad casum, se ha acusado a la Corte de actuar de manera arbitraria en la interpretación de los derechos de la Convención Americana de Derechos Humanos. Es un debate que está abierto. FerRer, Álvaro, et al., "Corte Interamericana de Derechos Humanos en el caso Atala Riffo y niñas vs. Chile: razones para afirmar la nulidad del proceso y la sentencia", Derecho Público Iberoamericano, Año 1, № 1, octubre 2012, pp. 201-239; PAúl, Álvaro, "La Corte Interamericana in Vitro: comentario sobre su proceso de toma de decisiones a propósito del caso Artavia", Derecho Público Iberoamericano, Año 1, № 2, abril 2013, pp. 303-345. Una amplia evaluación crítica, Verdugo, Sergio y García, José Francisco, "Radiografía al sistema interamericano de derechos humanos", Actualidad Jurídica, Año XIII, No 25, enero 2012, pp. 175-216.
} 
derechos humanos, se ha llegado a resultados efectivos, particularmente en el ámbito de la salud, aunque por vía indirecta, en razón de los derechos conexos o de la equidad ${ }^{63}$. La profesora Peña llega a una conclusión análoga, pero difiere en la premisa: no es a pesar sino con el concurso del contenido valórico de la Constitución y del principio de subsidiariedad-solidaridad, que ha sido posible obtener tales resultados ${ }^{64}$. A este respecto, se ha llamado la atención a una tendencia del Tribunal Constitucional chileno en orden a considerar los derechos sociales como canon hermenéutico a fin de dotarlos de protección constitucional ${ }^{65}$.

ii) La protección de la salud como derecho social justiciable. Es la propuesta del Prof. Figueroa en la que desbroza, desde el ángulo de las teorías anglosajonas, las objeciones comunes - de carácter político y jurídico- que suelen hacerse contra el rol activo de los jueces en este ámbito, particularmente en el derecho a la salud ${ }^{66}$.

Entiende el autor que, ante la parsimonia de los gobiernos, es papel de los jueces imponer la realización concreta del derecho a la salud, reasignando, a su modo, los recursos públicos. En ello no se afectan las decisiones presupuestarias al interior del diseño democrático, por cuando sólo se las está sometiendo a un control racional en orden a la vigencia universal de los derechos fundamentales.

Figueroa defiende la justiciabilidad de los derechos sociales. Deslegitima los criterios específicos de distinción entre éstos y los derechos civiles y políticos, tenidos como justiciables sin mayor problematización ${ }^{67}$. Todos los derechos, ensaya el autor, generan niveles distintos de obligaciones, de mayor o menor precisión. Obligaciones positivas o negativas, unas requieren la intervención del Estado y otras no, unas suponen costos, y otras los eximen. La justiciabilidad no dice relación con el género de los derechos (v. gr. civiles versus sociales) sino

\footnotetext{
${ }^{63}$ Hernández, Domingo, "Derechos económicos, sociales y culturales en la jurisprudencia de los tribunales superiores de justicia", en Nogueira, Humberto, Dogmática y aplicación de los derechos sociales. Doctrina y Jurisprudencia en Chile, Argentina y Perú, Librotecnia, Santiago, 2010, pp. 324-335.

${ }^{64}$ Peña, Marisol, "Aplicación de los derechos económicos, sociales y culturales por el Tribunal Constitucional chileno", en Nogueira, Humberto, Dogmática y aplicación de los derechos sociales, cit. nota n. 63, pp. 317-318.

${ }^{65}$ Henríquez, lan, "Los derechos económicos y sociales como canon hermenéutico (Tribunal Constitucional)", Revista de Derecho (Valdivia) vol. XXV, No 1, julio 2012, p. 242.

${ }^{66}$ FIGUeroA, Rodolfo, "Justificación del rol de las Cortes haciendo justiciables los derechos económicos, sociales y culturales, en particular, el derecho a la protección de la salud", Revista Chilena de Derecho,

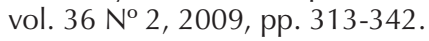

${ }^{67}$ En enfoque más restringido pero en la misma línea, ZúÑIGA, Alejandra, "Más allá de la caridad. De los derechos negativos a los deberes positivos generales", Revista de Derecho de la Pontifica Universidad Católica de Valparaíso, XXIII, $2^{\circ}$ semestre 2009, pp. 621-638.
} 
con la especial entidad de las obligaciones que originan, con la posibilidad de identificarlas y ejecutarlas ${ }^{68}$.

El aporte del autor nos permite hablar científicamente de "justiciabilidad", quizá de un modo en exceso funcional a la estructura institucional -gobierno, jueces, etc.- de la tradición norteamericana. Facilita de todos modos trabar en Chile una discusión seria sobre las eventuales consecuencias de unos derechos sociales justiciables, sea en relación con el derecho a la protección de la salud, sea en relación con la noción de Estado social y las técnicas administrativas de intervención.

Este punto lo ha abordado el Prof. Jordán. Reconoce que los derechos sociales de prestación no tienen, a nivel constitucional, la misma certeza configurativa que los derechos de libertad y que, en todo caso, es cierto que su satisfacción depende en gran parte de la capacidad económica del Estado. Empero, pondera que las técnicas de configuración legislativa y de concreción administrativa de estos derechos son estáticas y disfuncionales, y no se avienen con la exigencia dinámica de la tutela de los derechos fundamentales. Por ello propone, en una lectura de la jurisprudencia comparada, que sea el Tribunal Constitucional quien garantice procesalmente estos derechos por la vía de una tutela indirecta ${ }^{69}$.

Sin desmerecer la propuesta del Prof. Jordán, nosotros creemos que el derecho legislado y las técnicas del derecho administrativo económico tienen un papel central en la configuración de los derechos sociales, como mostraremos en su lugar. Y es deseable que así sea, por razones de seguridad jurídica.

iii) La protección de la salud como derecho social prestacional de eficacia inmediata. Es aproximativamente la propuesta de la Profesora Zúñiga. El derecho a la protección de la salud, en cuanto derecho social, es primordialmente un derecho prestacional, inmediatamente exigible y no programático, al menos en su núcleo mínimo ${ }^{70}$, por lo que se puede hablar de un derecho

\footnotetext{
${ }^{68}$ FigueroA, Rodolfo, "Justiciabilidad de los derechos económicos, sociales y culturales. Discusión teórica", Revista Chilena de Derecho, vol. 36, №3, 2009, pp. 587-620.

${ }^{69}$ JORDÁn, Tomás, "Elementos configuradores de la tutela jurisprudencial de los derechos educacionales en Chile", Estudios Constitucionales, Año 7, № 1, 2009, pp. 179-181. Más ampliamente, JORDÁN, Tomás, La protección de los Derechos Sociales: modelos comparados de tutela jurisprudencial (España y Chile), Universidad Alberto Hurtado, Colección de Investigaciones Jurídicas № 10, 2008. En línea parecida, con una lectura de la jurisprudencia constitucional de diversos países latinoamericanos, NASH, Claudio, "Los derechos económicos, sociales y culturales y la justicia constitucional latinoamericana: tendencias jurisprudenciales", Estudios Constitucionales, Año 9, № 1, 2011, pp. 65-118.

${ }^{70}$ ZÚNIIGA, "El derecho a la vida y el derecho a la protección de la salud", cit. nota n. 23, p. 50. Abona su postura con las siguientes sentencias: Silvia Peña Wasaff, Tribunal Constitucional, Recurso de Inaplicabilidad por inconstitucionalidad respecto del artículo 38 ter de la Ley $N^{\circ} 18.933,26$ de junio de 2008, y Tribunal Constitucional, Inconstitucionalidad iniciada de oficio en relación al artículo 38 ter de la Ley $\mathrm{N}^{\circ}$ 18.933, 6 de agosto de 2010, pp. 58-59.
} 
al "mínimo sanitario decente", concretado hoy en las Garantías Explícitas de Salud $(\mathrm{GES})^{71}$.

Es claro el fundamento de derecho positivo de esta postura si se restringe a estas garantías legales. Pero hay que subrayar la benemérita insistencia de la autora en este punto, así como su exigencia en recabar un carácter universal y de eficacia inmediata a las prestaciones de las GES, aporte de relevancia para la configuración del derecho en Chile.

Más allá de las GES, la autora presenta una justificación amplia del derecho prestacional a la salud, basada en los conocidos argumentos morales y políticos de la teoría de la justicia de Rawls, con algunos ajustes de la teoría de Norman Daniels sobre el cuidado sanitario ${ }^{72}$. Estos ideales que convencionalmente podemos denominar "igualitarios" parecen concebirse aquí como meta-finalidad del derecho prestacional de la salud. Su realización sería exigible a los tribunales de justicia. La pregunta que queda pendiente es si es factible, tanto desde el punto de vista teórico como práctico, vincular tan esencialmente la satisfacción jurídica de un derecho prestacional-siempre concreto-a la realización política de una igualdad teorética.

iv) La protección de la salud como derecho social prestacional no justiciable. Es la concepción del Prof. Martínez Estay. Los derechos sociales serían en lo sustancial, aunque no únicamente, derechos de prestación. Pero éstos "no pueden entenderse como facultades justiciables (derechos en sentido jurídico), sino más bien como aspiraciones o metas sociales constitucionalizadas ${ }^{\prime 73}$. Discrepando en este punto con Nogueira, Martínez afirma que esta sería la posición del constitucionalismo social, incluso del Pacto Internacional de Derechos Sociales, Económicos y Culturales.

En este cuadro, el derecho a la protección de la salud es concebido como un derecho social de prestación, dado que su satisfacción se realiza efectivamente través de prestaciones concretas. Pero en sede constitucional no puede hablarse de un derecho justiciable, dado que no está garantizado por el recurso de protección. Se trata de derechos de configuración legal, que no se bastan a sí mismos, teniendo como obvio límite legislativo la capacidad financiera del Estado $^{74}$.

\footnotetext{
${ }^{71}$ ZúÑIGA, Alejandra, "La teoría de la justicia para el cuidado sanitario", cit. nota n. 23.

72 ZúNIIGA, "La teoría de la justicia para el cuidado sanitario", cit. nota n. 23, pp. 114-123.

${ }^{73}$ Martínez Estay, José Ignacio, "Los derechos sociales de prestación en la jurisprudencia chilena", Estudios Constitucionales Año 8, № 2, 2010, p. 137; Bronfman, Martínez y NúNéez, "Constitución Política comentada", cit. nota n. 58, p. 223.

${ }^{74}$ Martínez Estay, José Ignacio, "Los derechos sociales de prestación", cit. nota n. 73, p. 133; Bronfman, Martínez y NúÑez, "Constitución Política comentada", cit. nota n. 58, p. 225. Una posición análoga en CovarRubias, Ignacio, "Un derecho a la salud que pretende garantizar el punto de llegada antes
} 
En lo justiciable se denota una abierta disparidad entre la tesis de Martínez Estay y las de Figueroa, Jordán y Zúñiga ${ }^{75}$. El punto de quiebre es lo que a grosso modo podría llamarse, en el análisis de Martínez, el principio de realidad: la determinación del valor y eficacia de un derecho concreto no depende de sistemas teóricos ni de bellas declaraciones (incluso jurisprudenciales), sino de su modulación legal y de las posibilidades reales de satisfacer su objeto. Concordamos en este punto con el Prof. Martínez, aunque creemos que no tiene mucho sentido hablar de derechos-prestaciones si en alguna dimensión, al interior del ordenamiento jurídico, no pueden hacerse exigibles. La tutela de los tribunales, aun a falta de configuración legal concreta, es uno de los modos que tienen los derechos sociales de articularse.

v) Nuestra postura: el enfoque teórico-práctico de la protección de la salud como derecho social plurivalente.

Las posturas anteriores dan cuenta, a nivel nacional, de la disparidad de opiniones existentes respecto de la naturaleza de los derechos sociales, y del marco teórico que lo hace comprensible.

Al respecto, propondremos nosotros una concepción de los derechos sociales que, por una parte busca integrar las ventajas de las posiciones precedentes, y, por otra, esquivar lo que nos parecen ser sus defectos. A esta opinión la llamaremos convencionalmente "derecho social plurivalente".

Nuestra concepción se formula teniendo en vista la necesidad de evitar los siguientes defectos:

a) Proyectar el marco teórico de los derechos sociales centrándose únicamente en la estructura del derecho. Como observa Díez-Picazo, los derechos fundamentales han de ser vistos no solo desde el punto de vista estructural (cuáles son las facultades o elementos jurídicos que comporta) sino también desde la óptica funcional (cuál es su finalidad garantizadora) ${ }^{76}$.

Una comprensión de los derechos sociales desde el criterio de su funcionalidad humana, lleva a subordinar la cuestión de la estructura a la mejor satisfacción de la propia finalidad del derecho.

que el punto de partida (sentencia de inconstitucionalidad del inciso tercero del artículo 38 Ter de la ley 18.993)", Instituto Libertad y Desarrollo, Sentencias Destacadas 2010, Santiago, LyD, 2011, pp. 83-84.

${ }^{75}$ Las sentencias del Tribunal Constitucional Roles $\mathrm{N}^{\circ} \mathrm{s} .976$ y 1710 que dan eficacia prestacional al derecho social a la protección de la salud, y que cita Zúñiga en su apoyo, son leídas aquí de un modo diverso, como un ejemplo del efecto horizontal de los derechos fundamentales. Martínez EstaY, José Ignacio, "Los derechos sociales de prestación", cit. nota n. 73, pp. 149-150. Aunque dicho efecto no parece haber sido bien comprendido por el TC chileno. Bronfman, Martínez y NúÑez, "Constitución Política comentada", cit. nota n. 58, p. 234.

${ }^{76}$ Dízz-PıCazo, Luis María, Sistema de Derechos Fundamentales, Thomsom-Civitas, Pamplona, 2008,

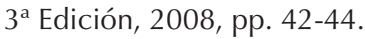


En este punto, es indudable que este tipo de derechos se funda en ciertas necesidades elementales de la naturaleza humana. En fórmula de Segovia, son derechos "que protegen una necesidad, una carencia, algo que no se tiene, pero que se necesita y desea". Son "créditos del hombre hacia la sociedad, derechos que amparan una posibilidad o garantizan una posición (muchas veces futura), cuya realización no depende ya directamente de las posibilidades individuales" $" 77$. En otras palabras, con Díez-Picazo, son derechos "que tienen como finalidad garantizar una vida digna ${ }^{178}$.

Si los derechos sociales son derechos puramente prestacionales, si son justiciables o no, o en qué grado, si tienen eficacia inmediata, etc., son problemas de estructura, que conceptualmente no pueden resolverse sin atender a su función garantizadora, considerada no sólo en abstracto, sino también en concreto, tal como ha sido formulada en sede jurídico-positiva.

La satisfacción paulatina de esta función lleva, según se observa en el derecho comparado, a que el Estado asuma la misión progresiva de articular un conjunto de instrumentos jurídicos de diversa naturaleza -derechos prestaciones, servicios universales, etc. - a fin de satisfacer los derechos sociales con un "elevado nivel de protección", según reza, por ejemplo, el artículo 35 de la Carta de los Derechos Fundamentales de la Unión Europea ${ }^{79}$.

b) Es necesario distinguir entre disertación ideológica y doctrina jurídica para precisar el concepto de derechos sociales. La ideología utiliza lo jurídico para la satisfacción de ciertos valores de la modernidad (hoy en discusión) que se asumen como un absoluto, como, por ejemplo, la libertad o la igualdad, con lo que se termina fomentando un discurso seductor sobre tales derechos, pero utópico y frustrante, por ausencia de medios económicos o acuerdos políticos para realizarlos en toda la línea de lo prometido ${ }^{80}$. Desmintiendo tales discursos hay que hacerse cargo de un hecho patente: la índole prestacional de muchos derechos sociales así como su carácter relativamente impreciso dificultan, en todo caso, su justiciabilidad, como ha reconocido el Tribunal Europeo de Derechos Humanos ${ }^{81}$.

\footnotetext{
${ }^{77}$ Segovia, Juan Fernando, Derechos humanos y constitucionalismo, Marcial Pons, Madrid-Barcelona, 2004, p. 47.

${ }^{78}$ Dírz-Picazo, Luis María, Sistema de Derechos Fundamentales, cit. nota n. 76, p. 43.

79 Monereo Pérez, José Luis, "Protección de la salud", en Monereo Atienza, Cristina y Monereo Pérez, José Luis (coords.), La Europa de los derechos. Estudio sistemático de la Carta de los derechos fundamentales de la Unión Europea, Comares, Granada, 2012, p. 942.

${ }^{80}$ COSTA, Jean Paul, "Vers une protection juridictionnelle des droit économiques et sociaux en Europe?", AA.Vv., Les droits de l'homme au seuil du troisieme millénaire: mélanges en hommage a Pierre Lambert, Bruylant, Bruselas, 2000, pp. 152-153.

${ }^{81}$ Morte Gómez, Carmen y Salinas Arcega, Sergio, "Los derechos económicos y sociales en la jurisprudencia del Tribunal Europeo de Derechos Humanos", en EmbiD IrUjo, Antonio (dir.), Derechos económicos y sociales, Madrid, lustel, 2009, pp. 365-366.
} 
De lo anterior se desprende que una acertada concepción de los derechos sociales no puede ni debe ser una pura elucubración teórica de buenos deseos o anhelos utópicos, desvinculada del todo del derecho normativo vigente. No existen derechos sociales en el papel. Si sus presupuestos de existencia y de efectividad dicen relación con la condición humana necesitada y el impulso civilizado hacia su satisfacción en pos de una vida digna, tales elementos sólo pueden ser configurados jurídicamente desde condiciones vitales y sociales concretas a través de medios económicos y humanos realmente disponibles en acto o en potencia. De ahí que nuestra concepción del derecho social plurivalente tenga necesariamente un enfoque teórico-práctico.

c) Es necesario superar la discusión terminológica acerca de los "derechos sociales". Hay quienes les parece demasiado ambiguo el rótulo, o en exceso vinculado a ciertas metas de un modelo de Estado hoy en declive. De ahí que algunos prefieran ubicar, por ejemplo, el derecho a la protección de la salud dentro de los "derechos de solidaridad", en el contexto de una visión más contemporánea de los valores constitucionales ${ }^{82}$. Lo fundamental es reconocer, más allá de las denominaciones, que existe una realidad jurídica tras los Ilamados "derechos sociales" en general, y la protección de la salud en particular, que debe ser garantizada positivamente y en diverso grado en cuanto a su exigibilidad o eficacia.

Todo lo anterior nos permite precisar, en un sentido afirmativo, en qué consiste la concepción teórico-práctica de los derechos sociales plurivalentes, que aplicaremos a la protección de la salud:

i) Nuestra concepción es "teórico-práctica" porque reivindica una delimitación de los derechos sociales atenta a las exigencias dogmáticas del derecho constitucional vigente, a su desarrollo legislativo y a sus modelos jurisdiccionales ${ }^{83}$.

ii) Es "plurivalente" porque integra en la noción de derechos sociales distintos elementos jurídicos -derechos, libertades, deberes estatales- determinados en mayor o menor medida por la capacidad política y económica del Estado y de la sociedad civil, en orden a satisfacer las condiciones de una vida digna para una población histórica concreta.

Los tres elementos señalados corresponden a las tres dimensiones modales a través de las cuales se manifiesta lo que denominamos "derecho social":

\footnotetext{
${ }^{82}$ Así lo hace la Carta Social Europea. Sobre el tema, Monereo Pérez, José Luis, "Protección de la salud", cit. nota n. 79, p. 940.

${ }^{83}$ En ese sentido, investigaciones como las del Prof. Baza, que en mayor o menor medida deslegitima el estatuto constitucional vigente, no entran en nuestro ámbito de análisis. BASSA, Jaime, El Estado constitucional de derecho. Efectos sobre la constitución vigente y los derechos sociales, LexisNexis, Santiago, 2008.
} 
"Protección de la salud, acceso a los medicamentos y deficiencias del mercado. Hacia un derecho social plurivalente en el marco de una economía social de mercado"

\section{* Como "derecho exigencia", faculta para exigir un beneficio o prestación determinada. \\ ** Como "derecho libertad", garantiza determinados ámbitos de autonomía o actuación. \\ *** Como deber del Estado se traduce en un deber general de promoción} y protección de aquellos bienes básicos que configuran la dimensión objetiva de los derechos sociales ${ }^{84}$. Se trata, en general, de deberes de "medios" y no de "resultados", que imperan la proyección y ejecución de políticas dirigidas a la mejora de tales o cuales derechos, por ejemplo, la protección de la salud ${ }^{85}$. Tales deberes no expresan simples metas o anhelos. Son concreciones normativas de principios jurídicos.

Esta taxonomía tripartita encaja con los distintos aportes de la doctrina nacional, porque conjuga los elementos jurídicos presentados por las diversas posiciones.

Encaja además con el derecho internacional de los derechos sociales, como se observa al analizar los diferentes instrumentos internacionales o comunitarios que los recogen ${ }^{86}$.

Estos elementos (derecho exigencia, derecho libertad, deberes estatales) encajan, en fin, según veremos en seguida, con las exigencias dogmáticas del actual estatuto chileno del derecho a la protección de la salud.

\footnotetext{
${ }^{84}$ Según la jurisprudencia constitucional española, los derechos fundamentales tienen una dimensión subjetiva (derechos subjetivos) y una dimensión objetiva (bienes o valores), a cuya "fuerza expansiva" el Estado se debe, al menos en cuanto a su promoción, y al margen de cualquier situación jurídica concreta. Extremando algo las cosas, la doctrina alemana conoce esta dimensión como "la concepción institucional de los derechos fundamentales". Dízz-Pıcazo, Luis María, Sistema de Derechos Fundamentales, cit. nota n. 76, pp. 63-64.

${ }^{85}$ Es la doctrina del Tribunal Europeo de Derechos Humanos, bastante pragmática, y coherente con el deber de promoción que la Constitución chilena impone al Estado respecto de los derechos del hombre (art. $5^{\circ}$ inciso segundo). El TEDH constata que los derechos sociales tienen un carácter justiciable muy diverso, y a veces nulo, pero que ello no supone que el Estado no asuma algún tipo de obligación. Llama a esas obligaciones de "medios" y no de "resultados", y van desde la implementación de un sistema de salud universal y de calidad hasta la consagración de derechos a través de fórmulas jurídicas lo suficientemente precisas. Morte Gómez, Carmen y Salinas Arcega, Sergio, "Los derechos económicos y sociales en la jurisprudencia del Tribunal Europeo de Derechos Humanos", cit. nota n. 81, pp. 373 y 375.

${ }^{86}$ En el caso de la protección de la salud, es particularmente visible la mención a los derechos exigencias y a los deberes estatales, por ejemplo, en el artículo 35 de la Carta de los Derechos Fundamentales de la Unión Europea (derechos de acceso a prestaciones y servicios, deberes estatales de implementación de políticas varias), en los artículos 11 y 13 de la Carta Social (derechos de acceso a servicios públicos y adecuados, derecho de prestación mínima a quien no disponga de recursos suficientes, políticas estatales diversas de acciones de salud), en el artículo 10 del Convenio de la OIT (contenido mínimo de prestaciones sanitarias, formuladas como derechos subjetivos), en el artículo 12 del Pacto Internacional de Derechos Económicos, Sociales y Culturales (derecho genérico a un nivel de vida adecuado, políticas de garantía y mejoramiento de las condiciones de salud). Monereo Pérez, José Luis, "Protección de la salud", cit. nota n. 79, pp. 939-941.
} 
Los derechos exigencias no están consagrados en nuestra Constitución. Pero ello no significa que no existan. Hay que preguntarse si acaso la ley los asegura. Vale decir, si ésta reconoce facultades a los chilenos para exigir prestaciones médicas concretas garantizadas por el Estado y, particularmente, cuál es su alcance en relación con los medicamentos ${ }^{87}$.

Examinado la legislación, es claro que se han configurado derechos de este tipo. Encontramos, en primer lugar, al Decreto con Fuerza de Ley $\mathrm{N}^{\circ} 1$ del MINSAL, del 24 de diciembre de 2006. En el artículo 131 incluye en el derecho constitucional a la protección de la salud no sólo un derecho negativo o de no intervención (la libre elección del sistema de salud) sino también un derecho afirmativo a exigir servicios y prestaciones (el libre e igualitario acceso a las acciones de promoción, protección y rehabilitación de la salud). Este último derecho, enunciado en general, se singulariza al menos en dos facultades concretas de acceso universal:

(a) El derecho a la atención de urgencia, en una institución pública o privada, no sujeta a condicionamientos o restricciones previas de carácter económico (artículos 141.2 y 3 y 141 bis.3);

(b) El derecho de recibir del Régimen General de Garantías de Salud un conjunto de prestaciones médicas (artículo 138) y recursos sanitarios específicos (artículo 141.1), comúnmente en los establecimientos asistenciales del Sistema Nacional de Servicios de Salud, sin que la eventual falta de capacidad de pago sea un obstáculo (artículo 132). En los recursos se incluyen los medicamentos contenidos en el Formulario Nacional (artículo 138 b), por lo que en este ámbito cabe hablar de un derecho de acceso a los medicamentos, garantizado por los órganos de salud del Estado.

En segundo lugar, tenemos las Garantías Explícitas de Salud, que la Ley № 19.966 define como derechos directamente exigibles por su titular: "Las Garantías Explícitas en Salud serán constitutivas de derechos para los beneficiarios y su cumplimiento podrá ser exigido por éstos ante el Fondo Nacional de Salud o las Instituciones de Salud Previsional, la Superintendencia de Salud y las demás instancias que correspondan" (artículo 2.2). Este derecho, de carácter subjetivo y prestacional, se extiende a un número determinado de prestaciones

\footnotetext{
${ }^{87}$ Probablemente se evitarían muchos desacuerdos en la doctrina chilena si habláramos más genéricamente de un derecho-exigencia en vez de un derecho prestación. El primero incluye a éste, pero lo supera. Con el derecho exigencia acentuamos la facultad antes que su objeto, de modo de incluir, v. gr., no sólo el ius in rem sino también el ius ad rem. Con lo cual a su vez se matizan las exigencias de justiciabilidad y de eficacia inmediata, las cuales dependen más de la existencia actual o futura del objeto que de la facultad. Esta definición, por lo demás, cuadra mucho mejor con el derecho de acceso a los medicamentos, que en muchos casos (por ejemplo, respecto de la exigencia de medicamentos bioequivalentes aún no homologados o autorizados) sólo podría concebirse, en sede de derecho subjetivo, como un ius ad rem.
} 
de salud garantizadas en su acceso, calidad, oportunidad y financiamiento (artículo 2.1 y artículo $4^{\circ}$ ).

Las Garantías Explícitas de Salud están a cargo no sólo de los prestadores públicos (FONASA), sino también de los privados (ISAPRES) (artículo 24). Respecto del sistema privado, corresponde a la Superintendencia de Salud velar por el cumplimiento de sus obligaciones legales, sea en lo que dice relación con las GES, sea en lo atingente a los contratos de salud (artículo 107).

De la legislación someramente citada se desprende que la protección de la salud en Chile incluye derechos-exigencias para acceder a prestaciones determinadas en forma y tiempo. Y que se traduce, como ha notado Zúñiga, en el derecho a exigir un estándar mínimo de atención de salud, garantizado por el Estado, particularmente intenso tratándose de enfermedades prioritarias (artículo 14 Ley $\left.\mathrm{N}^{\circ} 19.966\right)^{88}$. Ello, implica, dado el caso, el acceso universal a los medicamentos para los beneficiarios del GES en las patologías previstas.

Como derecho-exigencia, la protección de la salud también puede ser tutelada en sede jurisdiccional, aun a falta de configuración legal. Este punto ha sido suficientemente explorado por la doctrina chilena, con abundantes ejemplos en cuanto a resoluciones y tendencias, por lo que no parece necesario insistir en ello.

Como derecho social plurivalente, cual es nuestra propuesta, la protección de la salud incluye también otros dos elementos, que están explícitamente recogidos en la Constitución: derechos-libertades (para elegir los servicios y el sistema de salud público o privado) y deberes del Estado. Los primeros son de conocimiento común y no plantean mayores problemas, sin perjuicio de lo que digamos a propósito de los medicamentos. De los segundos, es oportuno identificar algunas de sus especies.

Ya precisamos, en general, en qué consisten estos deberes. Aquí anotamos que tienen una relevancia para nuestra Constitución que no ha sido suficientemente destacada. En el artículo $19 \mathrm{~N}^{\circ} 9$ se imponen deberes de carácter universal de promoción y de garantía sobre las acciones de salud.

El deber de promoción incluye políticas públicas sanitarias en el más amplio sentido de la palabra, como, por ejemplo, la política de medicamentos en curso, según veremos. El deber de garantía se traduce al menos en la obligación estatal de implementación de un servicio público de salud universal y permanente y en la supervigilancia del sistema privado respecto de las prestaciones que asegura y realiza.

El deber de garantía ha sido calificado como "derecho social" por el Tribunal Constitucional, precisando que el Estado tiene un deber preferente, respecto a

${ }^{88}$ ZúÑIGA, "La teoría de la justicia para el cuidado sanitario", cit. nota n. 23, pp. 129-130. 
los prestadores particulares, de ejecutar o garantizar la ejecución de las prestaciones de salud para la población. Este deber se concreta, en primer lugar, en la dictación de leyes y reglamentos que han de configurar un derecho a la protección de la salud cada vez más extensivo a partir del acceso a prestaciones determinadas. En segundo lugar, en la obligación de dar seguridad y certeza de que realmente se ejecuten las correspondientes acciones de salud, por parte del sector público y privado ${ }^{89}$.

Al delimitar la protección de la salud como derecho social, el Tribunal Constitucional chileno asume, sin decirlo explícitamente, que estamos ante un derecho que integra los tres elementos ya enunciados: derechos-libertades, derechos-exigencias, y deberes estatales, acentuando principalmente este último punto.

Lo que queda pendiente es acordar a partir de estos elementos una buena definición de derecho social en el plano de la salud. Creemos que una noción adecuada es la siguiente: un derecho social es la exigencia o imperativo jurídico, de fundamento natural o positivo, que impone al Estado el deber de proveer, progresiva pero realmente, de los bienes sociales esenciales a toda la población (en nuestro caso, las prestaciones de salud, y más en concreto, el acceso a los medicamentos), sea directamente, sea con el concurso subsidiario de la empresa privada (que puede ser o no lucrativa).

Hay que insistir en que los derechos sociales no pueden reducirse a facultades para exigir directamente al Estado prestaciones determinadas, aunque las suponga en diverso grado ${ }^{90}$. Los deberes estatales tienen tanto o más importancia que los derechos exigencias. Si el Estado chileno tiene el "deber preferente" de promover y garantizar la salud de los chilenos, como reza el artículo $19 \mathrm{~N}^{\circ} 9$ de la Constitución, es porque está obligado a su realización progresiva en todos los ámbitos jurídicos, particularmente en el área de los principios que inspiran una legislación configuradora de servicios de salud universales, con su adecuada traducción reglamentaria, y en el de las políticas públicas que implementan la disponibilidad, accesibilidad, oportunidad y calidad de dichos servicios. Una concreción de ello es la Ley No 19.937 que atribute al Ministerio de Salud la competencia para establecer estándares mínimos diferenciados de calidad que

\footnotetext{
${ }^{89}$ Tribunal Constitucional, Inconstitucionalidad iniciada de oficio en relación al artículo 38 ter de la Ley № 18.933, 6 de agosto de 2010, considerandos centésimo undécimo a centésimo vigésimo segundo, en: http://www.tribunalconstitucional.cl/wp/expedientes/buscador-de-expedientes? rol=1710wsdefrtg [visitado el 07/03/2013]. Una interpretación más controvertida, en sentido "rupturista", de la que no podemos hacernos cargo acá, en JORDÁN, Tomás, "El cambio del eje referenciador del derecho a la protección de la salud a partir de la jurisprudencia constitucional sobre el sub-sistema privado de salud", Estudios Constitucionales, Año 11, № 1, 2013, pp. 333-380.

${ }^{90}$ En análogo sentido, Díez-Picazo, Luis María, Sistema de Derechos Fundamentales, cit. nota n. 76, pp. 43-44.
} 
deben cumplir los prestadores institucionales de salud, tales como hospitales, clínicas, consultorios y centros médicos.

Si se mira la experiencia europea de lo que se denominan "derechos sociales" se constata que la mejor manera de realizarlos es precisamente a través de la implementación de servicios públicos, servicios universales o servicios de obligación de servicio público, adecuadamente estructurados en cuanto a su organización, funcionamiento, gestión y provisión para la satisfacción de las necesidades esenciales. Hay variadas fórmulas a través de las cuales el Estado obtiene financiamiento: lo importante, para los efectos jurídicos, es que si estos servicios quedan en manos privadas, se imponga siempre la carga de suministrarlos como actividad de interés general ${ }^{91}$. El Estado no necesita ser prestador directo, pero siempre es garante de que las actividades se presten en condiciones de calidad, accesibilidad e igualdad mínima ${ }^{92}$. Lo que en su ámbito se aplica también a la actividad de las farmacias.

Este marco teórico del la protección de la salud como derecho social plurivalente, modulado por deberes constitucionales del Estado de promoción y garantía, por principios jurídicos inspiradores de una legislación servicial, por políticas públicas coherentes y por derechos de exigencia concretos pero esenciales, es el que aplicaremos para concluir que existe en Chile un derecho social de acceso a los medicamentos en el contexto de una economía social de mercado. Previamente debemos aproximarnos a este último concepto.

\section{El MARCO TEÓRICO DEL ACCESO A LOS}

MEDICAMENTOS ANTE LAS DEFICIENCIAS DEL MERCADO (II):

LA ECONOMÍA SOCIAL DE MERCADO

El lugar más o menos amplio que una sociedad puede asignar al mercado en su economía varía según las distintas épocas históricas. Al respecto, y situándose dentro de los parámetros de la economía moderna, es conocida la tipología de Porket que distingue entre capitalismo de mercado (Market Capitalism), capitalismo dirigido (Command Capitalism), socialismo de mercado (Market Socialism) y socialismo dirigido (Command Socialism). Lo que vulgarmente se conoce como economía de mercado o basada en el mercado, Porket lo traduce

\footnotetext{
${ }^{91}$ Sobre el concepto de servicio universal y congéneres, MARTínez López-MuÑIz, José Luis, "Servicio público, servicio universal y 'obligación de servicio público' en la perspectiva del Derecho Comunitario: los servicios esenciales y sus regímenes alternativos", Administración de Andalucía, Revista andaluza de administración pública, № 39, 2000, pp. 25-52.

${ }_{92}$ Sobre la noción de Estado garante, y las nuevas técnicas del derecho administrativo económico, Mir Puigpelat, Oriol, Globalización y Estado de Derecho. Las transformaciones recientes del Derecho Administrativo, Thomson Civitas, Madrid, 2004, pp. 104-14. Sobre su relación con el Estado social, RESTREPO, Manuel, "La respuesta del derecho administrativo a las transformaciones recientes del Estado social de Derecho", Saberes, Revista de Estudios jurídicos, económicos y sociales, pp. 10-15.
} 
como capitalismo de mercado para connotar sus dos fundamentos característicos: la propiedad privada de los medios de producción y el mercado como mecanismo de coordinación de las decisiones económicas ${ }^{93}$.

Desde la óptica del derecho, el capitalismo de mercado no es un término unívoco, pues salvada la libertad económica, la propiedad privada y el funcionamiento mismo del mercado, hay muchas formas de modular la función reguladora del Estado, según los objetivos sociales y económicos que constitucional o legalmente se le asignen a éste (eficiencia y crecimiento económico, bienestar general, estabilidad, pleno empleo, defensa de la productividad, protección de la salud y garantía de seguridad social, etc.). Aquí, las taxonomías son infinitas. Ciñéndonos, por ejemplo, al debate interpretativo sobre la Constitución española, Gimeno Feliú habla de economía liberal de mercado, economía socializada de mercado o economía mixta de mercado, según el mayor o menor protagonismo que se atribuya a la iniciativa privada y al papel de la iniciativa pública (excepcional, concurrente y correctivo o intensivo) ${ }^{94}$. García Pelayo, por su parte, prefiere hablar de economía de libre mercado, economía social de mercado y economía dirigida de mercado, en función del grado de intervención del Estado social ${ }^{95}$.

La economía social de mercado (Soziale Marktwirtschaft) se ha perfilado durante mucho tiempo como una alternativa clara y definida a la economía liberal de mercado ${ }^{96}$. Alternativa que no consiste, como se cree, en una suerte de técnica jurídica para alcanzar objetivos igualitarios con la ayuda del Estado.

93 Porket, Joseph Ludovic, Modern Economic Systems and their transformation, St. Antony's Sries, Macmillan Press, 1998, pp. 14-18. Una interesante glosa aplicada al sistema económico español, alemán y europeo, en CiDOnCHA, La libertad de empresa, cit. nota n. 1, pp. 63-83.

${ }^{94}$ Gimeno Feluú, José María, "Sistema económico y derecho a la libertad de empresa versus reservas al Sector Público de actividades económicas", Revista de la Administración Pública, № 135 (1994), pp. 151- 163.

95 García Pelayo, Manuel, "Consideraciones sobre las cláusulas económicas en la Constitución", en Ramírez, Manuel (ed.), Estudios sobre la Constitución española de 1978, Pórtico, 1979, pp. 40-41.

${ }^{96}$ El término "liberal" es evidentemente convencional. Aunque la diferencia entre la economía social de mercado y las otras formas de economía de mercado parece clara, comporta diversas denominaciones según el ángulo de análisis del que se parta. Albert, v. gr., opone el modelo del Rhin al modelo neoamericano de los Estados Unidos, fundándose en el lugar que ocupa el mercado en la sociedad (o la garantía de seguridad social) para satisfacer las necesidades esenciales de la población. AlBERT, Capitalismo contra capitalismo, cit. nota n. 3. Thurow distingue entre el modelo del Rhin, el modelo anglosajón (a partir de la era Reagan y Thatcher, aunque con diferencias entre ambos) y el modelo japonés, según el compromiso comunitario o individualista del Estado. Thurow, Lester, The Future of Capitalism: how today's economic forces shape tomorrow's world: El futuro del capitalismo. Cómo la economía de hoy determina el mundo del mañana (traducción de Federico Villegas), (Javier Vergara Editor), Buenos Aires, Argentina, 1996. Los modelos no se han mantenido estáticos. Primero la globalización y después el escenario de crisis económica mundial han relativizado en las dos últimas décadas las diferencias entre estos modelos dentro del género economía de mercado, en beneficio 
El modelo en comento no es una mezcla de mercado con control estatal en pro de objetivos ideológicos. Tampoco es una composición incómoda entre economía de mercado y régimen centralizado de seguridad social y redistribución de riqueza, una suerte de "taller de reparaciones de los daños sociales provocados por el caos del capitalismo comercial"97. Lo esencial de una economía social de mercado es la concepción humanista de la economía, en virtud de la cual se reconoce que el mercado libre y competitivo debe subordinarse, como medio al fin, al aspecto más alto de la economía, cual es la comunicación del bienestar para todos. Entendiéndose que el bienestar se ordena a su vez a los aspectos no económicos de la vida en sociedad. Por ello, más que un sistema, la economía social de mercado es un orden ${ }^{98}$, un estilo ${ }^{99}$, una cultura económica no centralista ni racionalista, que prohíbe calcular sin contar con los hombres ${ }^{100}$.

El artículo $3 \mathrm{~N}^{\circ} 3$ del Tratado de Lisboa, vigente desde el 1 de diciembre del 2009, considera explícitamente a la economía social de mercado como el modelo rector vinculante para la Unión Europea ${ }^{101}$. Su objetivo no es sólo el crecimiento económico sobre la base de un mercado libre y competitivo sino también la protección social. El rendimiento económico comporta riesgos humanos al interior de la sociedad que deben ser corregidos y compensados por un programa social amplio y variado inspirado en los principios de subsidiariedad, solidaridad y participación ${ }^{102}$. Las técnicas de derecho administrativo

del paradigma neoamericano. Es algo que ya entreveía Albert en 1991 al prevenir que pese a la superioridad económica y social de la Soziale Marktwirtschaft germana, su retroceso era inminente ante el impulso de la economía financiera y su paradigma de ganancia a corto plazo. AlBert, Capitalismo contra capitalismo, cit. nota n. 3, pp. 159-171.

${ }^{97}$ MiralbelL, Ignacio, "La economía de mercado de Ludwig Erhardt y el futuro del Estado de Bienestar", Empresa y Humanismo, Cuaderno No 62, s/f, p. 6.

${ }^{98}$ ERHARD, Ludwig, Economía Social de Mercado. Su valor permanente (traducción de Ignacio Miralbell), Rialp, Madrid, 1994, pp. 35-69; EuCKEN, Walter, Grundsätze der Wirtschaftspolitik, J.C.B. Mohr (Paul Siebeck), Tübingen, 1990, pp. 370-374.

${ }_{99}$ Broyer, Sylvain, "The Social Market Economy: Birth of an Economic Style", Wissenschaftzentrum Berlin Für Sozialforshung, august 1996, pp. 1-17.

${ }^{100}$ RÖPKE, Wilhelm, Jenseits von Angebot und Nachfrage: Más allá de la oferta y la demanda (traducción de Marciano Villanueva), Unión Editorial, Madrid, 1996, 2ª ed., pp. 120-160, 287-316.

${ }^{101}$ El artículo $3 \mathrm{~N}^{\circ} 3$ del Tratado de Lisboa dispone que los Estados miembros de la Unión obrarán "en pro del desarrollo sostenible de Europa basado en un crecimiento económico equilibrado y en la estabilidad de los precios, en una economía social de mercado altamente competitiva, tendente al pleno empleo y al progreso social, y en un nivel elevado de protección y mejora de la calidad del medio ambiente".

102 JOHN, Klaus-Dieter, "Die Soziale Marktwirtschaft im Kontext der Europäischen Integration. Befund und Perspektiven", en HaufF, Michael von (Hg.), Die Zukunftsfähigkeit der Sozialen Marktwirtschaft, Marburg, 2007, pp. 143-191; SChallenberG, Peter y Berenz, Thomas, "Soziale Marktwirtschaft für Europa?", Kirche und Gesellschaft, Nr. 387, februar 2012, pp. 1-16. 
que se utilicen para tales efectos se dejan a la competencia de cada Estado miembro ${ }^{103}$.

En la doctrina constitucional chilena parece hablarse indistintamente de economía de mercado, economía de libre mercado o economía social de mercado, suponiendo que a menor regulación estatal la economía de mercado funciona siempre mejor. La concepción cambia a la hora de contrastar este modelo con eventuales exigencias de un Estado social, sea desde un punto de vista estrictamente jurídico ${ }^{104}$, sea desde el ángulo de la ciencia política ${ }^{105}$.

Desde el ámbito del modelo económico, notan Schlecht, Rüstow y MüllerArmack, que la economía de libre mercado es un mecanismo económico extremadamente funcional, por lo que requiere ser inserto en una ordenación humanista de todos los bienes, capaz de corregir o compensar el proceso puramente técnico de producción de riquezas y aumento de capital. Sólo al interior de un orden supra-económico es que el mercado puede cumplir su función social, superando la captura parcializada del inmoderado afán de lucro, del interés de poderosos grupos privados de carácter sectorial, o del ansia de dominio del

\footnotetext{
${ }^{103}$ Una interpretación problemática del artículo 3 № 3 del Tratado de Lisboa, resaltando la tensión entre el progreso social y las exigencias puramente económicas del mercado "altamente competitivo", en MAESTRO, Gonzalo, El tratado de Lisboa y la constitución económica. Dirección Web en Bibliografía. Una interpretación opuesta, acentuando la armonización entre los dos elementos, en COMECE, Eine Europäische Solidaritäts- und Verantwortungsgemeinschaft, Brüssel, 2011, pp. 15-25.

${ }^{104}$ Tempranamente Solari avanzó la interesante tesis de que la Constitución de 1980 configuraría un Estado social de derecho. Soları, Enzo, "Recepción en Chile del Estado Social de Derecho", Revista Chilena de Derecho, vol. 20, № 2-3, 1993, pp. 336-344. Nash y Milos niegan materialmente el precedente, pero por la vía de la remisión constitucional a los instrumentos internacionales de derechos humanos, conciben también un estado social de derecho en Chile. NASH, Claudio y MıLOS, Catalina, "Estado social y democrático de derecho en Chile: tan cerca y tan lejos", Anuario de Derecho Constitucional Latinoamericano, Año XVII, Montevideo, 2011, pp. 90-93. pp. 167-170. No podemos hacernos cargo aquí de esta discusión.

${ }^{105}$ Frickhöffer sostuvo en su época que las bases de la economía de mercado instaurada en Chile se asimilaban a las de la economía social en Alemania, por su alto grado de flexibilidad, productividad y racionalidad. FrICKHÖFFER, Wolfgang, "La implantación de una economía de mercado: el modelo alemán y el modelo chileno", Estudios Públicos № 6, 1982, pp. 89-98. Lazcano rechaza la similitud, al menos durante el gobierno militar, dado el influjo de la Escuela de Chicago en el modelo chileno. LASCANO, Iván, El Ordoliberalismo alemán y la economía social de mercado, UNAB, México, 2008, pp. 168-169. En el mismo sentido, con mayor acopio bibliográfico, Huneeus, Carlos, "Los cambios institucionales al sistema económico durante la transición a la democracia en Chile. Del neoliberalismo a la economía social de mercado", Revista Ciencia Política, Universidad de Chile, vol. XX, № 2, 2000, pp. 103-115. Por su parte, Yáñez niega que se pueda hablar de economía social de mercado en Chile, pues pese al progreso económico, los avances en aquella dirección no son sustanciales en todas las materias relevantes: función social de la propiedad, necesidades de vivienda y alimentación, sistema de salud y de pensiones, relación empresarios-trabajadores, desigualdad notable en la distribución de ingresos. Yáñez, Eugenio, "La vía chilena hacia una economía social de mercado?", Acontecimiento, № 60, 2001, pp. 7-9. Más ampliamente, Yáñez, Eugenio, Economía social de mercado en Chile ¿Mito o realidad?, Hanns Seidel Stiftung, Santiago, 2005.
} 
mismo Estado. Este es el axioma basal de la economía social de mercado, que a la lógica del rendimiento utilitario acompaña la lógica de la compensación social, cuidando del equilibrio entre libertad, responsabilidad y orden ${ }^{106}$.

Recalcamos en este punto algo que ha pasado desapercibido en nuestra doctrina constitucional: el modelo de economía social de mercado parece ajustarse mejor a las bases económicas y sociales de nuestra Constitución política que la economía liberal de mercado, que distorsiona el principio de subsidiariedad, reduciendo al Estado a la más mínima expresión en lo relativo a la regulación económica. El principio de que el Estado sólo debiera incidir en los mercados por la exigua vía de la policía administrativa, dado que la fijación de condiciones subjetivas u objetivas de intercambio vulnerarían per se la libertad de los agentes económicos, es un vulgarismo que no resiste análisis serio, al menos desde la perspectiva del derecho público económico ${ }^{107}$. En la imposibilidad de analizar extensivamente este punto, connotamos que en el ámbito del mercado de medicamentos durante décadas se ha defendido este errado principio, acompañado de una noción de libertad económica que ha inhibido su función social, dislocando el principio de subsidiariedad a un ámbito puramente pasivo.

En este sentido, la realización de la protección de la salud y del acceso a los medicamentos en el marco del mercado, pasa por volver a recomponer la función social de éste, superando los límites distorsionadores de la ideología economicista, sin caer en los excesos de la utopía igualitaria ${ }^{108}$. Para tales efectos, el modelo de economía social de mercado, alejado de todo exceso de ideologismo, hace posible que el Estado y los cuerpos intermedios intervengan realmente en los déficits del mercado, entregando herramientas jurídicas que, según examinaremos en concreto en el próximo acápite, respetan por una parte la libertad de los agentes económicos y, por otra, permiten dar satisfacción adecuada a los derechos sociales, en particular, al derecho a la protección de la salud, en condiciones mínimas pero satisfactorias de igualdad material.

\footnotetext{
${ }^{106}$ MülLer-ArMACK, Genealogie der Sozialen Marktwirtschaft. Frühschriften und weiterführende Konzepte, Haupt, Bern/Stuttgart, 1981, pp. 100-110; SCHLECHT, Otto, Grundlagen und Perspektiven der Sozialen Marktwirtschaft, Tübingen, Mohr, 1990, pp. 89-201; Rüstow, Alexander, "Wirtschaft als Dienerin der Menschlichkeit", Aktionsgemeinschaft Soziale Marktwirtschaft Tagungsprotokoll $\mathrm{N}^{\circ}$ 15, 1960, Luisburgo, pp. 7-16; Schallenberg y Berenz, "Soziale Marktwirtschaft für Europa?", Kirche und Gesellschaft, № 387, februar 2012, pp. 4-9.

${ }^{107}$ Sobre las amplias posibilidades de la regulación económica en armonía con la competencia del mercado, ARIÑO, Gaspar, La regulación económica. Teoría y práctica de la regulación para la competencia, Dapalma, Buenos Aires, 1996, pp. 61-153.

${ }^{108}$ Los excesos del igualitarismo como ideología, en GrAf, Hans, Ihr werdet sein wie Gott. Der Irrtum des modernen Menschen von der Französischen Revolution bis heute, Herbig-Universitas, München, 1988, pp. 100-455; FernándeZ de LA Mora, La envidia igualitaria, Planeta, Madrid, pp. 125-136, 194-232.
} 
Se puede hablar de este modo de un derecho a la protección de la salud en el contexto de una economía social de mercado, con una concepción activa del principio de subsidiariedad, que supone poner en juego el sub-principio de solidaridad o compensación social.

\section{El ACCESO A LOS MEDICAMENTOS: UN DERECHO}

SOCIAL PLURIVALENTE EN EL CUADRO DE UNA ECONOMÍA SOCIAL DE MERCADO

El acceso a los medicamentos es el derecho de la población a obtener regularmente medicamentos para la prevención y el tratamiento de las enfermedades, realizado progresivamente a través de políticas y planes públicos que aseguren precios accesibles, financiación sostenible, sistema de suministros fiables y un uso racional de ellos ${ }^{109}$. Se parte de la cobertura de los medicamentos esenciales, para ir extendiendo poco a poco la garantía de acuerdo a la mejor capacidad financiera o de gestión del Estado.

En nuestro país, el acceso a los medicamentos es un componente implícito del derecho a la protección de la salud reconocido en el artículo 19 № 9 de la Constitución, pues la salud no se puede proteger o recuperar sin los medicamentos apropiados. Son insumos esenciales a las prestaciones de salud.

Para delimitar bien la extensión del acceso a los medicamentos hay que considerar que es un "derecho social" en el sentido que le venimos dando al término. Es decir, se trata de un derecho plurivalente compuesto por los siguientes elementos jurídicos:

1) Deberes del Estado que derivan implícitamente de aquellos que la Constitución impone en materia de salud. Los deberes de garantía son fundamentalmente dos. Del "deber preferente de garantizar la ejecución de las acciones de salud" emana el deber de proveer medicamentos de calidad suficiente para el acceso oportuno de la población, sea directamente a través del sistema público, sea indirectamente a través del privado. En segundo lugar, del deber de garantizar el "libre e igualitario acceso a las acciones de promoción, protección, y recuperación de la salud, y rehabilitación del individuo", surge la obligación de extender el acceso ("acceso" tiene aquí el sentido fuerte que ya hemos definido) a los medicamentos dispensados por las farmacias, a partir de su distribución, importación o producción.

Esta última garantía se traduce en el deber más particular del Estado, hoy notoriamente incumplido, de regular el mercado de medicamentos jerarquizando y armonizando los intereses de todos los sectores (productores, distri-

109 Organización Mundial de la Salud (OMS), cit. nota n. 27, pp. 2-6. La delimitación jurídica del acceso a los medicamentos como componente del derecho a la salud, y desde diversos enfoques, BARRANCO Vela, Rafael (director), Bombillar Saenz, Francisco Miguel (coordinador), El acceso al medicamento, Comares, Granada, 2010. 
buidores, profesionales de la salud, dispensadores, pacientes, consumidores), teniendo claro que la concurrencia de la empresa privada debe ajustarse al interés general de la salud y no sólo a su libertad económica de marginar utilidades para sí misma. De ahí el imperativo de generar una legislación que sin afectar necesariamente la lógica de la libre competencia incentive el buen comportamiento de los agentes del mercado mediante la regulación, información y control de la actividad de interés general que prestan los laboratorios, droguerías y farmacias.

Esta preocupación ha quedado reflejada en al menos diecisiete proyectos de ley que actualmente (mayo 2013) se tramitan en el Congreso, de desigual valoración en cuanto a su coherencia y efectividad ${ }^{110}$. Podemos destacar dos:

a) El proyecto de ley que reforma el Código Sanitario (Boletines $\mathrm{N}^{\circ} \mathrm{s}$. 6.523$11,6.037-11,6.331-11,6858-11$, refundidos), en lo referente a la regulación de las farmacias y los medicamentos. Existe consenso en impedir los incentivos económicos ilegítimos en la prescripción y dispensación de medicamentos, en dignificar la receta médica, en reivindicar el rol del químico farmacéutico, en transparentar la oferta de productos, en mejorar la información comparativa de precios al servicio del usuario, etc. Se espera, con la colaboración de todos los involucrados, obtener una reforma que enmiende sustantivamente las falencias en la comercialización de los medicamentos y en la información asimétrica en perjuicio del consumidor.

\footnotetext{
110 Proyecto de Ley que regula los incentivos comerciales a la venta de medicamentos que se expenden bajo receta médica (Boletín 6037-11); Proyecto que establece un precio fijo de venta para los productos farmacéuticos que componen el Formulario Nacional de Medicamentos (Boletín 6331-11); Proyecto que permite vender en supermercados medicamentos que no requieren receta médica (Boletín 6455-11); Proyecto que establece la obligación de las farmacias de vender medicamentos genéricos de manera directa al público (Boletín 6468-11); Proyecto sobre receta médica (Boletín 8281-11); Proyecto que modifica el Código Sanitario, estableciendo la facultad de prescribir medicamentos por los profesionales de la enfermería (Boletín 8298-11); Proyecto que modifica el artículo 113 del Código Sanitario, dando a los optometristas la facultad de emitir recetas médicas (Boletín 8339-11); Proyecto que actualiza el Libro X del Código Sanitario (Boletín 8359-11); Proyecto que establece modificaciones al Código Sanitario en relación a la obligación de exhibir los precios de los medicamentos (Boletín 8464-11); Proyecto que agrega nuevo artículo al Código Sanitario, que establece una información en línea de los precios de medicamentos (Boletín 8481-11); Proyecto que modifica Decreto con Fuerza de Ley $N^{\circ}$ 1, del Ministerio de Salud, para asegurar el acceso igualitario a las distintas modalidades de atención para los beneficiarios del régimen de prestaciones de salud (Boletín 5915-11); Proyecto sobre enfermedades poco frecuentes (Boletín 7643-11); Proyecto que adecua el Decreto con Fuerza de Ley $N^{\circ} 1$ de Salud de 2005, a la Ley $N^{\circ} 20.575$ que establece el principio de finalidad en el tratamiento de datos personales (Boletín 8222-11); Proyecto que modifica el sistema privado de salud (Boletín 7955-11); Proyecto que establece la obligatoriedad de contratar un seguro de salud a los extranjeros que ingresan al país (Boletín 8946-11); Proyecto que modifica el art. 173 del Decreto Ley $N^{\circ}$ 1, de 2006, que fija el texto refundido, coordinado y sistematizado del Decreto Ley $N^{\circ} 2.763$, de 1979 y de las Leyes $\mathrm{N}^{\circ}$ s. 18.933 y 18.469 , con el objeto de impedir y sancionar, la integración vertical de instituciones previsionales de salud y, prestadores de beneficios de salud (Boletín 8792-11); Proyecto que crea la Agencia Nacional de Medicamentos (Boletín 8783-11).
} 
b) El proyecto de ley que crea la Agencia Nacional de Medicamentos (Boletín № 8783, del 27 de diciembre del 2012), servicio público descentralizado abocado exclusivamente al control de calidad de los medicamentos y otros productos de uso médico, así como al registro de los mismos. Lo que se intenta es garantizar a la población el acceso a medicamentos de calidad comprobada.

La reforma al Código Sanitario probablemente cohibirá los incentivos perversos del lucro en la dispensación de los medicamentos en el mercado. Y el mayor control de la calidad influirá en un mejor acceso a los medicamentos que se proveen en los servicios públicos de salud, lo que beneficia al sector más vulnerable de la población. Pero sólo indirectamente solucionará la tendencia al alza del precio de los productos farmacéuticos y su incidencia en el bolsillo del paciente.

2) El segundo elemento que compone el derecho social de acceso a los medicamentos es el derecho-libertad de los usuarios para decidir cuál es el modo de acceder a los productos farmacéuticos de acuerdo al sistema de garantía elegido o comprometido en la ejecución de las prestaciones de salud. Esta libertad, implícita en la Constitución, se extiende a la dispensación de las farmacias, de acuerdo con las normas de prescripción médica, seguridad y uso racional de los medicamentos.

3) El tercer elemento es integrado por los derechos-exigencias. Se trata de derechos subjetivos de acceso a los medicamentos que en su concreción requieren ser configurados por ley. En la actualidad existen expresamente en el ámbito de las Garantías Explícitas de Salud, habiéndose definido el titular, el objeto y las condiciones de su ejercicio de acuerdo a las necesidades terapéuticas de las enfermedades prioritarias. Su efectividad se ve mermada, sin embargo, como vimos, por algunos problemas en la universalidad de estas garantías así como en su aplicación ${ }^{111}$.

4) El cuarto y último elemento por razones metodológicas lo separamos de los anteriores. Se trata de los deberes estatales de promoción que se traducen en políticas públicas de realización efectiva de los elementos precedentes. Al respecto es de destacar la Política de Medicamentos en la Reforma de Salud del año 2004 cuyo objetivo primordial es "asegurar la disponibilidad y acceso a toda la población de los medicamentos indispensables, contenidos en el Formulario Nacional, de eficacia y calidad garantizada, seguros, de costo asequible y cuyo uso racional lleve a conseguir los máximos beneficios en la salud de las personas como en el control del gasto que ellos representan'1212. Esta política nacional

\footnotetext{
111 ZÚÑIIGA, "El derecho a la vida y el derecho a la protección de la salud", cit. nota n. 23, pp. 54-55; ZúñIGA, Alejandra, "El derecho a la salud en el Plan Auge", Informe anual sobre derechos humanos en Chile 2007, Centro Derechos Humanos, Universidad Diego Portales, Santiago, 2007, pp. 211-214.

112 Ministerio de Salud, Política Nacional de Medicamentos en la Reforma de Salud, aprobada por Resolución Exenta № 515 del 2 de abril del 2004 del Ministerio de Salud, p. 17.
} 
de medicamentos se encuentra vigente y se viene aplicando en lo sustancial en el marco de la compra y abastecimiento de fármacos e insumos médicos de CENABAST, aunque no sin controversias sobre la calidad y seguridad de los medicamentos y sobre el mejoramiento de la estructura, funcionamiento y gestión de esta institución. A partir del año 2012, se han reforzado líneas de acción para hacer efectivas, dentro del sistema de salud, las garantías en el acceso, calidad y disponibilidad de medicamentos del Formulario Nacional ${ }^{113}$.

Pero fuera de las prestaciones que se ejecutan al interior del sistema público de salud, estas políticas gubernamentales poco han podido hacer para superar las analizadas grandes falencias de nuestro mercado de medicamentos.

Es por eso que se hace necesario extender el derecho, que ya postulamos como plurivalente, al interior del propio mercado. Para lo cual hay que evitar caer en dos extremos:

a) El extremo de la parálisis. En él se incurre cuando sólo se proyectan medidas de incentivo a la competencia como solución a los problemas del mercado de medicamentos. Tras dichas medidas se palpa la concepción ideológica del mercado como un mecanismo sagrado, intocable, que por principio auto-regula satisfactoria y suficientemente sus propias imperfecciones.

b) El extremo del exceso de actividad estatal. En él se cae cada vez que el Estado olvida su función subsidiaria, y hace de la decisión central-administrativa el eje de la satisfacción de los derechos sociales, sustituyendo o erradicando la iniciativa privada y la participación de los cuerpos intermedios en el proceso de satisfacción de dichos derechos. Con lo que afecta a su vez el dinamismo económico de la legítima concurrencia de los agentes privados.

Postulamos, entonces, que la extensión del derecho social de la protección de la salud al interior del mercado de medicamentos debe hacerse dentro de un marco jurídico-económico apropiado. "Jurídico-económico" y no puramente "jurídico", porque creemos que en este plano se han de evitar las instituciones de diseño bien intencionado pero no sustentables económicamente. Dicho marco nos parece que se encuentra en la economía social de mercado, de acuerdo a los lineamientos que ya hemos revisado.

A tales efectos se han de tener en cuenta los siguientes principios:

1) No basta con comprobar que el mercado chileno no está suficientemente regulado, con regulación conforme al mercado ${ }^{114}$. Es necesario dar un paso más

\footnotetext{
113 Gobierno de Chile, Dirección de Presupuesto, "Política e Institucionalidad para la compra y abastecimiento de fármacos e insumos médicos", Anexo I de Evaluación Comprehensiva del Gasto de la Cenabast, enero 2012, pp. 1-12.

${ }^{114} \mathrm{Al}$ respecto, no deja de tener relevancia la obligación, impuesta por vía reglamentaria a las farmacias, en orden a disponer en forma clara y simple de medicamentos con bioequivalencia demostrada (27 de diciembre del 2012). La venta de bioequivalentes, podrá, en condiciones óptimas, servir de alternativa a los medicamentos "de marca", rompiendo el círculo vicioso del estilo de negocios oligopólico.
} 
y sostener sin ambages que el padrón regulatorio del mercado de medicamentos es supra-mercantil. Está constituido por la necesidad de interés general de que los medicamentos se provean a toda la población y en condiciones dignas, dado el grado de desarrollo del país. El mercado sirve a este interés, debe ser una herramienta direccionada a ese fin, puesto que los medicamentos que se transan a través de sus mecanismos son, en sí mismo considerados, bienes esenciales a la naturaleza humana, no enteramente ajustables a la noción de bien comercial.

En otros términos, si la protección de la salud es un derecho fundamental, fundado no en el lucro sino en la dignidad humana necesitada, no queda otra opción sino afirmar que el mercado es un medio que debe estar al servicio de la buena provisión de medicamentos, y no al exclusivo beneficio de los agentes económicos productivos que participan en él. Para lo cual, en sede de los derechos sociales, ha de tenerse en cuenta las características imperfectas del mercado de medicamentos chilenos y del mercado mundial, tendentes a la concentración económica y al tratamiento del proceso de producción y distribución del medicamento como un negocio más ${ }^{115}$. Y, por otro lado, reconocer los beneficios del mercado y de la libre empresa en su justa medida, lo que constitucionalmente supone el respeto de los derechos fundamentales concurrentes a la protección de la salud, como la propiedad privada o la libertad empresarial.

2) El Estado tiene la obligación de intervenir en el ámbito privado cuando este no alcanza sus fines (subsidiariedad activa). De este modo, si el acceso a los medicamentos es un derecho social, el Estado ha de garantizarlo en las condiciones adecuadas (precio, disponibilidad, calidad, etc.) también al interior del mercado, en la medida en que éste no provea a tal acceso. Y lo hará incidiendo directamente en dicho mercado a través de técnicas de regulación económica específicas.

En el mercado de medicamentos no basta, como se ha hecho hasta aquí, con la regulación básica de los intercambios económicos, v. gr., las leyes civiles y mercantiles, imprescindibles para la garantía y buen orden de la libertad contractual. Tampoco es suficiente la sola regulación externa (seguridad, medio ambiente, etc.) propia de las actividades económicas de carácter puramente privado. El mercado de medicamentos es una actividad esencialmente vincu-

\footnotetext{
Queda pendiente, sin embargo, la controversia sobre la actual acreditación de su calidad respecto de productores carentes de Buenas Prácticas de Manufactura (GMP en inglés).

${ }^{115}$ La industria farmacéutica mundial parece estar atenazada en la producción de medicamentos por dos intereses contrapuestos: el lucro y el interés científico-tecnológico. PÁEZ MORENO, Ricardo, "La investigación de la industria farmacéutica: ¿condicionada por los intereses del mercado?", Acta Bioethica 2011; 17 (2) pp. 237-246. Algunos fundados en investigaciones fácticas o judiciales sostienen la tesis de que el interés científico-tecnológico se ha subordinado completamente al lucro. UGALDE, Antonio y HOMEDES, Nuria, "Medicamentos para lucrar. La transformación de la industria farmacéutica", Salud Colectiva, Buenos Aires 5 (3) septiembre-diciembre 2009, pp. 305-309.
} 
lada al interés general en razón de su objeto. En consecuencia, en virtud de su propia naturaleza, pide una técnica de regulación económica interna que garantice dicho interés general, estableciendo exigencias o requisitos especiales tanto al sujeto que realiza la actividad como a la actividad misma: capacitación especial y solvencia de conocimientos técnicos, mayor intensidad en la garantía de los productos (calidad, origen, etiquetado, etc.), modalidades particulares en la prestación de los servicios (no sólo la venta en pro de utilidades), en la responsabilidad, en la publicidad, etc.

A modo indicativo es conveniente estudiar a futuro el diseño de al menos dos técnicas de mayor densidad regulatoria al interior del mercado, con el objeto de incidir directamente en los problemas de acceso a los medicamentos que hemos revisado. Tomadas del derecho comparado, habría que analizar su factibilidad técnica y su modulación en Chile:

a) Es imperativo que los medicamentos esenciales estén vinculados no solo a la noción de bien comercial privado, sino también al de bien de interés general, mediante un modelo jurídico de farmacia que lo garantice, superando la estructura del establecimiento puramente económico. En la Unión Europea hay múltiples ejemplos, entre los que se destaca la exigencia de farmacia profesional y sostenible o de farmacia privada de interés público ${ }^{116}$.

b) Parece oportuno establecer una regulación de precios en la que participen todos los actores involucrados, incluyendo al Estado, con el objeto de asegurar la racionalidad en la marginalización de utilidades, la transparencia en el lucro y la responsabilidad social ${ }^{117}$.

Las intervenciones precedentes se ajustan a los requerimientos de la economía social de mercado, que, respetando la libertad, la canaliza hacia los objetivos sociales propios de la provisión de bienes y de servicios esenciales. Hace parte de la compensación social que exige el modelo, dando satisfacción adecuada a derechos como la salud.

\footnotetext{
${ }^{116}$ Las técnicas de regulación sobre las distintas variables del modelo de farmacias europeo, ANTOÑANZAS, "Los medicamentos en la Unión Europea: el tándem comercio-salud", cit. nota n. 53, pp. 151-167. Un enfoque descriptivo de algunos elementos del modelo de farmacias, Consejo General de ColeGios Oficiales de Farmacéuticos, Modelos de farmacia en la Unión Europea, Informe diciembre 2007, pp. 3-38. Dirección Web en Bibliografía. Una visión problemática ante la crisis del euro, Consejo General De ColeGios Oficiales de Farmacéuticos, Anuario de la Comunidad del Medicamento 2012, Madrid-Barcelona, 2012, pp. 18, 184-185. Dirección Web en Bibliografía Citada. Sobre aspectos aparentemente conflictivos con la libertad de empresa, pero en el fondo compatibles, Pérez Gálvez, Juan Francisco, "Libertad de establecimiento de farmacias en la Unión Europea", Revista de Derecho de la Pontificia Universidad Católica de Valparaíso, XXXV, 2010, 2º Semestre, pp. 361-406.

${ }^{117}$ Ejemplos indicativos en Espín BAlBino, Jaime, El sector farmacéutico y los medicamentos en la Unión Europea: una aproximación a los restos actuales, Escuela Andaluza de Salud Pública, Granada, 2004, pp. 45-55. Para Chile, evaluando sus ventajas, aunque sin adelantarse a recomendarlo en las conclusiones, VasSallo, El mercado, cit. nota n. 28, pp. 104-109.
} 
Una observación final. Desde la perspectiva socio-económica, es razonable pensar que el mercado puede colocar toda la fuerza de su eficacia y gestión al servicio del acceso a los medicamentos (mayor calidad, menor precio, mejor disponibilidad), desde que realmente sea competitivo, libre y respetuoso de todos los intereses concurrentes (oferentes, proveedores y demandantes). De hecho, el mecanismo del mercado es utilizado, a su modo, por el Estado en el proceso de compras públicas. Y fuera de la provisión a los servicios públicos, en las farmacias privadas se colocan a disposición del ciudadano medicamentos de calidad, con importantes dosis de satisfacción. Incluso cuando hay competencia, aunque insuficiente, se notan diferencias en los precios ${ }^{118}$.

No se trata, en consecuencia, de demoler ni el mercado de la salud en general ni el mercado de medicamentos en particular, sino de reconocer sus deficiencias estructurales y funcionales a fin de compensarlas con mediaciones jurídicas que permitan una intervención correctiva del Estado y de los cuerpos intermedios (intervenciones participativas), respetando, por otro lado, la imagen maestra del mercado, esto es, la iniciativa económica y el libre intercambio en lo que tienen de esencial.

\section{CONCLUSIÓN}

Del análisis de conjunto, se imponen las siguientes conclusiones:

1. El derecho a la protección de la salud está siendo afectado por deficiencias del mercado, particularmente en uno de sus componentes esenciales, cual es el acceso a los medicamentos.

2. Las deficiencias apuntan a graves problemas en la estructura y el funcionamiento del mercado chileno, que han terminado por subordinar las prestaciones de salud y el acceso a los medicamentos, en especial de los éticos, a la marginación de utilidades de grandes productores y distribuidores, en menoscabo del beneficio de usuarios/pacientes/clientes, vulnerando de paso principios elementales de la libre competencia y del derecho del consumidor.

3. Las deficiencias indicadas son veladas o justificadas por una concepción ideológica del mercado que atribuye erróneamente a este mecanismo la capacidad de solucionar por sí mismo sus propios defectos. Con lo que se inhibe la legítima intervención del Estado y de los cuerpos intermedios al interior del mercado, excluyendo por principio aquellas técnicas de regulación económica que, por un lado, respetan la iniciativa privada y el libre intercambio y, por otro, salvaguardan el interés general implicado en ellas.

118 Servicio Nacional del Consumidor (Sernac), Seis Monitoreos Mensuales de productos farmacéuticos en Farmacias, Área Metropolitana, de marzo a julio 2012, sobre la base de más de trescientos medicamentos. Dirección Web en Bibliografía Citada. 
"Protección de la salud, acceso a los medicamentos y deficiencias del mercado. Hacia un derecho social plurivalente en el marco de una economía social de mercado"

4. Se hace necesario, en consecuencia, proponer una noción adecuada de la protección de la salud a fin de extender su vigencia al interior del mercado de medicamentos. Dicha adecuación pasa por teorizar el problema ajustándose al actual estatuto constitucional y legal.

5. Desde este ángulo teórico-práctico se puede recabar una concepción plurivalente de la salud como derecho social, abarcando tres dimensiones fundantes: los derechos libertades, los derechos exigencias y los deberes estatales, particularmente los de promoción y garantía. Los derechos exigencias pueden ser tutelados por distintas vías en sede jurisdiccional, incluso a falta de configuración legal según los casos. Pero hay aquí un problema de previsibilidad difícil de resolver.

6. A todo evento, la concepción plurivalente permite afirmar en lo mínimo que en Chile existe, a nivel constitucional y legal, un derecho social a la protección de la salud, que se manifiesta con distinto grado de realización en las tres dimensiones referidas (libertades, derechos-exigencias, deberes estatales). Lo que desde un ángulo específico se vuelve operativo con la existencia legal de derechos exigencias y la promoción administrativa de políticas públicas, todas en orden a garantizar el acceso y disponibilidad de los medicamentos en el sistema nacional de servicios de salud y en el régimen de garantías explícitas de salud. Subsisten, no obstante, deficiencias puntuales en la calidad y cobertura universal de los medicamentos, que, se estima, se irán subsanando con el tiempo.

7. El problema decisivo se encuentra al interior del mercado de medicamentos donde, desde un punto de vista fáctico, el derecho social plurivalente a la protección de la salud parece no tener cabida. Al respecto, se impone la necesidad de extender este derecho a dicho ámbito. $Y$ debe hacerse dentro de un marco jurídico-económico que permita intervenir en el mercado con mayor o menor densidad regulatoria, para asegurar el acceso a los medicamentos, según lo exija el principio de subsidiariedad y de compensación social, respetando siempre la imagen maestra del mercado y los derechos fundamentales que en él concurren.

8. El marco bajo el cual cabe esta intervención, en plena armonía con las bases socio-económicas de nuestra carta constitucional, es, estimamos, la economía social de mercado, tal como se ha delineado en este trabajo, de acuerdo a los principios explicitados. Se trata de un marco "jurídico-económico", no puramente jurídico, con lo que se evita la tentación de diseñar instituciones bienintencionadas pero carentes de sustentabilidad.

9. Bajo el paradigma de la economía social de mercado se permiten técnicas de regulación intensas que inciden en el mecanismo del libre intercambio, imponiendo, si es necesario, requisitos adicionales tanto al sujeto que realiza la actividad de mercado como a la actividad misma, condicionándola en algunos de sus factores. En este orden, proponemos indicativamente evaluar dos medidas 
para intervenir directamente en el mercado de medicamentos chileno a fin de dar vigencia a la protección de la salud: la exigencia de un modelo jurídico de farmacia que garantice la no consideración exclusivista del medicamento como bien mercantil y la regulación participativa de los precios (que no es lo mismo que su fijación estatal). Ambas soluciones no afectan en lo esencial las libertades económicas. Se utilizan al interior del derecho comunitario europeo en el marco de la economía social de mercado, cuyo fin no es sólo la eficiencia acumulativa de ingresos, sino también el bienestar para todos.

10. Creemos que el concepto teórico-práctico de derecho social en el cuadro de una economía social de mercado, que aquí se ha perfilado, es útil para sostener que la protección de la salud y el acceso a los medicamentos no es un ideal político ni una consigna ideológica, sino un verdadero y estricto derecho, que puede configurarse a distintos niveles dentro de la lógica de nuestro ordenamiento jurídico.

\section{BiBLIOGRAFÍA CITADA}

Aedo, Cristián, "Las reformas en la salud en Chile", en Larraín, Felipe y Vergara, Rodrigo (eds.), La transformación económica de Chile, CEP, Santiago, 2001, pp. 605-640.

AlBERT, Michel, Capitalisme contre capitalisme: Capitalismo contra capitalismo (traducción de José Federico Delos), Paidos, Buenos Aires-Barcelona-México, 1997.

Antoñanzas, Fernando, Rodríguez, Roberto, SaCRISTÁn, José Antonio, IlLA, Rafael, "Los medicamentos en la Unión Europea: el tándem comercio-salud", Gaceta Sanitaria, 2005, № 19 (2), pp. 151-167.

ARIÑO, Gaspar, La regulación económica. Teoría y práctica de la regulación para la competencia, Dapalma, Buenos Aires, 1996.

Arruñada, Benito, Economía de la empresa. Un enfoque contractual, Ariel, Madrid, 1990.

Barranco Vela, Rafael (director), Bombillar Saenz, Francisco Miguel (coordinador), El acceso al medicamento, Comares, Granada, 2010.

Betancor, Andrés, Regulación; mito y derecho. Desmontando el mito para controlar la intervención de los reguladores económicos, Civitas-Thomson Reuters, Navarra, 2010.

Bronfman, Alan; Martínez, José Ignacio y Núñez, Manuel, Constitución Política comentada. Parte Dogmática. Doctrina y Jurisprudencia, Abeledo Perrot, Santiago, 2012.

Broyer, Sylvain, "The Social Market Economy: Birth of an Economic Style", Wissenschaftzentrum Berlin Für Sozialforshung, august 1996, pp. 1-17. 
BRUCKNER, Peter, Misère de la prosperité. La religion marchande et ses ennemis: Miseria de la prosperidad. La religión del mercado y sus enemigos (traducción de Amelia Ros), Tusquets, Barcelona, 2003.

BULNES, Luz, "El derecho a la protección de la salud en la Constitución de 1980", Gaceta Jurídica 295 (1), 2005, pp. 12-29.

CAstillo, Leonardo, Colusión en mercados relevantes: un aporte a la discusión, Flacso-Chile, 2009, 11 pp. En: http://issuu.com/flacso.chile/docs/ de_colusion_2009 [visitado el 17/01/2013].

CEA, José Luis, Derecho Constitucional Chileno. Santiago, Ediciones Universidad Católica, Santiago, 2012, Tomo II.

CidonCha, Antonio, La libertad de empresa, Thomson Civitas-Aranzadi-Instituto de Estudios Económicos, Cizur Menor, 2006.

СОMECE, Eine Europäische Solidaritäts- und Verantwortungsgemeinschaft, Brüssel, 2011, 29 pp.

En: http://www.katolsk.dk/uploads/media/EconomyDE.pdf [visitado el 02/05/2013].

Consejo General de Colegios Oficiales de Farmacéuticos, Modelos de Farmacias de la Unión Europea, Madrid-Barcelona, diciembre 2007, 38 pp. En: http:// www.portalfarma.com/Profesionales/farmaciainternacional/Documents/ FarmaEuropa2007.pdf [visitado el 14/04/2013].

Consejo General de Colegios Oficiales de Farmacéuticos, Anuario de la Comunidad del Medicamento 2012, Madrid-Barcelona, 2012, 256 pp. En: http:// www.contenidos-files.com/elglobal/documentacionpdf/Anuario2012.pdf [visitado el 10/05/2013].

COSTA, Jean Paul, "Vers une protection juridictionnelle des droit économiques et sociaux en Europe?", en AA.Vv., Les droits de I'homme au seuil du troisieme millénaire: mélanges en hommage a Pierre Lambert, Bruylant, Bruselas, 2000, pp. 141-154.

Couso, Javier y ReYES, Mauricio, "Notas acerca del origen y trayectoria del derecho constitucional a la protección a la salud en Chile", Revista de Derecho de la Universidad Católica del Norte, 2009, № 2, pp. 161-194.

Covarrubias, Ignacio, "Un derecho a la salud que pretende garantizar el punto de llegada antes que el punto de partida (sentencia de inconstitucionalidad del inciso tercero del artículo 38 Ter de la ley 18.993)", InSTITUTO LIBERTAD Y Desarrollo, Sentencias Destacadas 2010, Santiago, LyD, 2011, pp. 67-99.

Cruz Parcero, Juan Antonio, El lenguaje de los derechos. Ensayo para una teoría estructural de los derechos, Trotta, Madrid, 2007.

Danzon, Patricia M. y Furukawa, Michael F., Prices And Availability Of Pharmaceuticals: Evidence From Nine Countries, Health Affairs, 2005, 16 pp. En: http://healthnewsdaily.elsevierbi.com/ /media/Images/Publications/Archive/ 
The\%20Pink\%20Sheet/65/044/00650440021/031103_health_affairs_rx_pricing.pdf [visitado el 05/12/2012].

Darnaculleta, María Mercè, Derecho Administrativo y Autorregulación: la autorregulación regulada, Universitat de Girona, Girona, 2003.

Díez-PICAzo, Luis María, Sistema de Derechos Fundamentales, Thomsom-Civitas, Pamplona, $3^{\text {a }}$ edición, 2008.

Dumont, Louis, Homo aequalis. Genèse et épanouissement de l'idéologie économique: Homo aequalis. Génesis y apogeo de la ideología económica (traducción de Juan Aranzadi), Taurus, Madrid, 1999.

El Mercurio, "Estudio internacional ubica a Chile entre sistemas de salud privados más caros del mundo", Economía y Negocios, 27 de marzo del 2013.

ERHARD, Ludwig, Economía Social de Mercado. Su valor permanente (traducción de Ignacio Miralbell), Rialp, Madrid, 1994.

EuCKen, Walter, Grundsätze der Wirtschaftspolitik, J.C.B. Mohr (Paul Siebeck), Tübingen, 1990.

Ferrer, Álvaro; Domínguez, Carmen; Romero, Alejandro; Bustamante, Reynaldo, "Corte Interamericana de Derechos Humanos en el caso Atala Riffo y niñas vs. Chile: razones para afirmar la nulidad del proceso y la sentencia", Derecho Público Iberoamericano, Año 1 № 1, octubre 2012, pp. 201-239.

Fernández de la Mora, Gonzalo, La envidia igualitaria, Planeta, Madrid. 1984. FigueroA, Rodolfo, "Justificación del rol de las Cortes haciendo justiciables los derechos económicos, sociales y culturales, en particular, el derecho a la protección de la salud", Revista Chilena de Derecho, vol. 36 № 2, 2009, pp. 313-342.

, "Justiciabilidad de los derechos económicos, sociales y culturales. Discusión teórica", Revista Chilena de Derecho, vol. 36, № 3, 2009, pp. 587-620.

Fiscalía Nacional Económica, Mercado de la salud privada en Chile. Estudio solicitado a la Pontificia Universidad Católica de Valparaíso, octubre 2012, 210p. En: http://www.fne.gob.cl/wp-content/uploads/2012/11/INFORMEPUCV-MERCADO-SALUD.pdf [visitado el 28/04/2013].

FrICKHÖFFER, Wolfgang, "La implantación de una economía de mercado: el modelo alemán y el modelo chileno", Estudios Públicos 6, 1982, pp. 89-98.

GALBRAITH, John Kenneth, Naciones ricas, naciones pobres. Ensayos sobre la persuasión política y económica, Ariel, Barcelona, 1986.

García Pelayo, Manuel, "Consideraciones sobre las cláusulas económicas en la Constitución", en Ramírez, Manuel (ed.), Estudios sobre la Constitución española de 1978, Pórtico, 1979, pp. 29-35.

Ghersı, Enrique, "El mito del neoliberalismo", Estudios Públicos, 95, 2004, pp. 293-313. 
Gimeno Feliú, José María, "Sistema económico y derecho a la libertad de empresa versus reservas al Sector Público de actividades económicas", Revista de la Administración Pública, № 135, 1994, pp. 149-212.

Gobierno de Chile, Dirección de presupuesto, "Política e Institucionalidad para la compra y abastecimiento de fármacos e insumos médicos", Anexo I de Evaluación Comprehensiva del Gasto de la Cenabast, enero 2012, pp. 1-12.

Graf, Hans, Ihr werdet sein wie Gott. Der Irrtum des modernen Menschen von der Französischen Revolution bis heute, Herbig-Universitas, München, 1988.

Henríquez, Miriam, "El derecho a la protección de la salud", en Aguilar, Gonzalo (coord.), Derechos económicos, sociales y culturales en el orden constitucional chileno, Librotecnia, Santiago, 2012, pp. 433-448.

Henríquez, lan, "Los derechos económicos y sociales como canon hermenéutico (Tribunal Constitucional)", Revista de Derecho (Valdivia), vol. XXV, № 1, julio 2012, pp. 237-242.

Hernández, Domingo, "Derechos económicos, sociales y culturales en la jurisprudencia de los tribunales superiores de justicia", en Nogueira, Humberto, Dogmática y aplicación de los derechos sociales. Doctrina y Jurisprudencia en Chile, Argentina y Perú, Librotecnia, Santiago, 2010, pp. 319-340.

HuneEus, Carlos, "Los cambios institucionales al sistema económico durante la transición a la democracia en Chile. Del neoliberalismo a la economía social de mercado", Revista Ciencia Política, Universidad de Chile, vol. XX, № 2, 2000, pp. 103-130.

International Federation of Health, Plans 2012 Comparative Price Report Variation in Medical and Hospital Prices by Country. En: http://www.ifhp.com/d ocuments/2012iFHPPriceReportFINALApril3.pdf [visitado el 30/04/2013].

JoHN, Klaus-Dieter, "Die Soziale Marktwirtschaft im Kontext der Europäischen Integration. Befund und Perspektiven", en Hauff, Michael von (Hg.), Die Zukunftsfähigkeit der Sozialen Marktwirtschaft, Marburg, 2007, pp. 143191.

JORDÁN, Tomás, "Elementos configuradores de la tutela jurisprudencial de los derechos educacionales en Chile", Estudios Constitucionales, Año 7, № 1, 2009, pp. 177-207.

, La protección de los Derechos Sociales: modelos comparados de tutela jurisprudencial (España y Chile), Universidad Alberto Hurtado, Colección de Investigaciones Jurídicas № 10, 2008.

La Segunda, "Clínicas privadas en la mira Cirugías y exámenes en Chile se consideran entre los más caros del mundo", 23 de marzo del 2013.

LASCANO, Iván, El Ordoliberalismo alemán y la economía social de mercado, UNAB, México, 2008. 
LIPSEY, Richard G., Introducción a la economía positiva, Vicens-Vives, Barcelona, 1989, $3^{a}$ reimpresión.

MaESTRO, Gonzalo, El tratado de Lisboa y la constitución económica. En: http:// www.ugr.es/ redce/REDCE9/articulos/03GonzaloMaestroBuelga.htm\#dos [visitado el 02/05/2013].

Mangiamel, Stelio, "La liberalización de los servicios en la Unión Europea", Revista de Derecho Constitucional Europeo, № 8, julio-diciembre de 2007, pp. 75-93.

Mankiw, Nicholas Gregory, Principles of Economics: Principios de Economía (traducción de Ester Rabasco), Mc Graw Hill, México, 1999.

Martínez Estay, José Ignacio, "Los derechos sociales de prestación en la jurisprudencia chilena", Estudios Constitucionales Año 8, № 2, 2010, pp. 125166.

Martínez López-MuÑiz, José Luis, "Servicio público, servicio universal y 'obligación de servicio público' en la perspectiva del Derecho Comunitario: los servicios esenciales y sus regímenes alternativos", Administración de Andalucía, Revista andaluza de administración pública, № 39, 2000, pp. 25-52.

Ministerio de EConomía, Fomento y Turismo. División de Estudios, El mercado de medicamentos en Chile, estudio basado en la información proporcionada por IMS Health, el Ministerio de Salud y el Instituto de Salud Pública, abril 2013. En: www.economia.gob.cl/wp.../04/Boletin-Mercado-de-Medicamentos.pdf [visitado el 12/05/2013].

Ministerio de Salud, Política Nacional de Medicamentos en la Reforma de Salud, aprobada por resolución exenta NN$^{\circ} 515$ del 2 de abril del 2004 del Ministerio de Salud. En: http://www.ssrv.cl/docs/farmacia/Politica_de_Medicamentos/ Politica_Nacional_Medicamentos.pdf [visitado el 05/05/2013].

, Comisión de Reforma de la Salud, Minuta Política Nacional de Medicamentos en el contexto de la Reforma de Salud, Santiago, abril 2004. En: http:// ciperchile.cl/wp-content/uploads/estudio-comision-reforma-de-la-salud.pdf [visitado el 07/02/2013].

Subsecretaría de Salud Pública, Departamento de Políticas farmacéuticas y PROFESIONES MÉDICAS, Manual de Selección de Medicamentos: metodología para la selección de medicamentos del Formulario Nacional y arsenales farmacoterapéuticos de los establecimientos de salud, 2010. En: http:// www.minsal.gob.cl/portal/url/item/8da1a881754303ade04001011 f01670 a.pdf [visitado el 03/01/2013].

, Reglamento sobre información de precio de productos farmacéuticos y productos en general al interior de farmacias y almacenes farmacéuticos, Decreto $N^{\circ} 142$ del 10 de diciembre del 2009. Vigencia desde el 1 de febrero del 2011. 
Mir PuigPelat, Oriol, Globalización y Estado de Derecho. Las transformaciones recientes del Derecho Administrativo, Thomson Civitas, Madrid, 2004.

MiralbelL, Ignacio, "La economía de mercado de Ludwig Erhardt y el futuro del Estado de Bienestar", Empresa y Humanismo, Cuaderno No 62, s/f. En: http:// www.unav.es/empresayhumanismo/publicaciones/cuadernos/catalogo06. htm [visitado 23/04/2013].

Monereo Atienza, Cristina y Monereo Pérez, Jose Luis (coords.), "La Europa de los derechos. Estudio sistemático de la Carta de los derechos fundamentales de la Unión Europea", Comares, Granada, 2012.

Morte Gómez, Carmen y Salinas Arcega, Sergio, "Los derechos económicos y sociales en la jurisprudencia del Tribunal Europeo de Derechos Humanos", en Embid IRujo, Antonio (dir.), Derechos económicos y sociales, Madrid, lustel, 2009, pp. 359-412.

Müller-Armack, Genealogie der Sozialen Marktwirtschaft. Frühschriften und weiterführende Konzepte, Haupt, Bern/Stuttgart, 1981.

Muñoz, Francisco Javier, Dispersión de Precios y Costos de Búsqueda en el Mercado Farmacéutico Chileno, Instituto de Economía de la Pontificia Universidad Católica, Santiago, 2011.

Nancuante, Ulises y Sotomayor, Roberto, El derecho de la salud, ConoSur, Santiago, 2001.

NASH, Claudio, "Los derechos económicos, sociales y culturales y la justicia constitucional latinoamericana: tendencias jurisprudenciales", Estudios Constitucionales, Año 9, № 1, 2011, pp. 65-118.

NASH, Claudio y Mııos, Catalina, "Estado social y democrático de derecho en Chile: tan cerca y tan lejos", Anuario de Derecho Constitucional Latinoamericano, Año XVII, Montevideo, 2011, pp. 79-100.

Nogueira Alcalé, Humberto, "Los derechos económicos, sociales y culturales como derechos fundamentales efectivos en el constitucionalismo democrático latinoamericano", Estudios Constitucionales, Año 7, № 2, 2009, pp. 143-205.

, Derechos fundamentales y garantías constitucionales. Los derechos sociales fundamentales, Centro de Estudios Constitucionales de Chile, Librotecnia, Santiago, 2009.

, "La protección de los derechos sociales como derechos fundamentales de eficacia inmediata y justiciables en jurisdicción constitucional: la sentencia del Tribunal Constitucional Rol 1710-2010-INC, del 6 de agosto del 2010, sobre la inconstitucionalidad del artículo 38 Ter de la Ley de Isapres", Estudios Constitucionales, Año 8, № 2, 2010.

Organization for Economic Co-operation and Development (OECD), Competition Committee, Competition in Hospital Service, 5 de junio 2012 [DAF/ 
COMP(2012)]. En: http://www.oecd.org/regreform/sectors/50527122.pdf [visitado el 17/01/2013].

Organización Mundial de la Salud (OMS), Perspectivas políticas de la OMS sobre medicamentos, Documento 8: Acceso equitativo a los medicamentos esenciales: un marco para la acción colectiva, Ginebra, marzo 2004. En: http://archives.who.int/tbs/ndp/s4964s.pdf [visitado el 07/01/2013].

PÁez Moreno, Ricardo, "La investigación de la industria farmacéutica: ¿condicionada por los intereses del mercado?", Acta Bioethica 2011; 17 (2), pp. 237-246.

PAúl, Álvaro, "La Corte Interamericana in Vitro: comentario sobre su proceso de toma de decisiones a propósito del caso Artavia", Derecho Público Iberoamericano, Año 1, № 2, abril 2013, pp. 303-345.

PeÑa, Marisol, "Aplicación de los derechos económicos, sociales y culturales por el Tribunal Constitucional chileno", en Nogueira, Humberto, Dogmática y aplicación de los derechos sociales. Doctrina y Jurisprudencia en Chile, Argentina y Perú, Librotecnia, Santiago, 2010, pp. 299-318.

Pérez Gálvez, Juan Francisco, "Libertad de establecimiento de farmacias en la Unión Europea", Revista de Derecho de la Pontificia Universidad Católica de Valparaiso, XXXV, 2010, 2 Semestre, pp. 361-406.

PietTre, Andre, Les trois âges de l'économie: Las tres edades de la economía (traducción de Fernando Aguirre), Rialp, Madrid, 1962.

Polanyı, Karl, The Livelihood of Man: El sustento del hombre (traducción de Ester Gómez), Barcelona, Mondadori, 1994.

Porket, Joseph Ludovic, Modern Economic Systems and their transformation, St. Antony's Sries, Macmillan Press, 1998.

RESTREPO, Manuel, "La respuesta del derecho administrativo a las transformaciones recientes del Estado social de Derecho", Saberes, Revista de Estudios jurídicos, económicos y sociales, Volumen 5, Año 2007, separata, pp. 1-18.

Román, Óscar y MuÑoz Félix, "Una mirada crítica en torno al plan AUGE: Algunos aspectos generales y valóricos", Revista Médica de Chile 2008, 136, pp. 1599-1603

RÖPKE, Wilhelm, Jenseits von Angebot und Nachfrage: Más allá de la oferta y la demanda (traducción de Marciano Villanueva), Unión Editorial, Madrid, 1996, $2^{\text {a }}$ ed.

, "Más allá de la oferta y la demanda", Fomento de Cultura, Valencia, 1960.

, "La crisis social de nuestro tiempo", Revista de Occidente, Madrid, 1947.

, "Civitas humana", Revista de Occidente, Madrid, 1956. 
Rosanvallon, Pierre, El capitalismo utópico. Historia de la idea de mercado, Ediciones Nueva Visión, Buenos Aires, 2006.

Rüstow, Alexander, "Wirtschaft als Dienerin der Menschlichkeit", Aktionsgemeinschaft Soziale Marktwirtschaft Tagungsprotokoll No 15, 1960, Luisburgo, pp. 7-17.

SANDEL, Michael J., What Money can't buy. The moral limits of markets, Farrar, Straus and Giroux, New York, 2012.

SegoviA, Juan Fernando, Derechos humanos y constitucionalismo, Marcial Pons, Madrid-Barcelona, 2004.

Senado de la República, Comisión de Salud, Primer Informe, 15 de julio 2010 sobre reforma del Código Sanitario (Boletines $\mathrm{N}^{\circ}$ s. 6.523-11, 6.037-11 y 6.331-11, refundidos).

, Comisión de SAlud, Segundo Informe, 3 de enero 2012 sobre reforma del Código Sanitario (Boletines $N^{\circ}$ s. 6.523-11, 6.037-11 y 6.331-11, refundidos).

Servicio Nacional del Consumidor (Sernac), Estudio de precios de prestaciones médicas del 17 de octubre del 2011, sobre la base de 64 prestaciones, insumos y medicamentos vigentes al 24 de agosto de 2011, en dieciséis instituciones de la región Metropolitana. En: http://www.sernac.cl/26020/ [visitado el 05/11/2012].

, Estudio de precios de medicamentos bioequivalentes del 29 de octubre del 2012. En: http://www.sernac.cl/estudio-hasta-20-veces-menos-puedecostar-un-medicamento-bioequivalente/ [visitado el 20/11/2012].

Seis Monitoreos Mensuales de productos farmacéuticos en Farmacias, Área Metropolitana, de marzo a julio 2012, sobre la base de más de trescientos medicamentos. En: http://www.sernac.cl/25980000 [visitado el 14/08/2013].

Silva Bascuñán Alejandro, Tratado de Derecho Constitucional. De los derechos y deberes constitucionales, Editorial Jurídica de Chile, Santiago, 2008, Tomo XII.

Schallenberg, Peter y Berenz, Thomas, "Soziale Marktwirtschaft für Europa?", Kirche und Gesellschaft, Nr. 387, februar 2012, pp. 1-16.

SCHLECHT, Otto, Grundlagen und Perspektiven der Sozialen Marktwirtschaft, Tübingen, Mohr, 1990.

Stıglitz, Joseph, Micoeconomía, Ariel, 1993.

Soları, Enzo, "Recepción en Chile del Estado Social de Derecho", Revista Chilena de Derecho, vol. 20, № 2-3, 1993, pp. 333-344.

SuÁrez, Christian, "Los derechos económicos y sociales en la Constitución Chilena y los límites de la jurisprudencia", en NogueirA, Humberto (coord.), 
Dogmática y aplicación de los derechos sociales, Librotecnia, Santiago, 2010, pp. 96-172.

Thurow, Lester, The Future of Capitalism: how today's economic forces shape tomorrow's world: El futuro del capitalismo. Cómo la economía de hoy determina el mundo del mañana (traducción de Federico Villegas), (Javier Vergara Editor), Buenos Aires, Argentina, 1996.

Treanor, Paul, Neoliberalism: origins, theory, definition, diciembre 2005. En: http://web.inter.nl.net/users/Paul.Treanor/neoliberalism.html [visitado el 05/02/2013].

Ugalde, Antonio y Homedes, Nuria, "Medicamentos para lucrar. La transformación de la industria farmacéutica", Salud Colectiva, Buenos Aires 5 (3) septiembre-diciembre 2009, pp. 305-322.

VAldÉS PRIETO, Domingo, Libre competencia y monopolio, Editorial Jurídica, Santiago, 2009.

Vallet de Gortisolo, Juan, Ideología, Praxis y Mito de la Tecnocracia, Montecorvo, Madrid, 1975.

VÁsquez, José Ignacio, "El déficit garantístico del artículo 19 No 9 de la Constitución", en Actas XXXIV Jornadas de Derecho Público, LexisNexis, Santiago, 2005.

Vassallo, Carlos, El mercado de medicamentos en Chile: caracterización y recomendaciones para la regulación económica. Informe solicitado por el Colegio de Químicos Farmacéuticos de Chile, junio 2010. En: http://www. colegiofarmaceutico.cl/2012/archivos/Mercado_medicamentos_chile.pdf [visitado el 02/01/2013].

Verdugo, Sergio y García, José Francisco, "Radiografía al sistema interamericano de derechos humanos", Actualidad Jurídica, Año XIII, № 25, enero 2012, pp. 175-216.

YÁÑEZ, Eugenio, "La vía chilena hacia una economía social de mercado?", Acontecimiento, $\mathrm{N}^{\circ}$ 60, 2001, pp. 9-11.

, Economía social de mercado en Chile ¿Mito o realidad?, Hanns Seidel Stiftung, Santiago, 2005.

ZúñIGA, Alejandra. "Sistemas sanitarios y reforma Auge en Chile", Acta Bioethica 2007, 13 (2), pp. 237-245.

, "El derecho a la salud en el Plan Auge", Informe anual sobre derechos humanos en Chile 2007, Centro Derechos Humanos, Universidad Diego Portales, Santiago, 2007, pp. 207-236.

, "Más allá de la caridad. De los derechos negativos a los deberes positivos generales", Revista de Derecho de la Pontifica Universidad Católica de Valparaíso, XXIII, $2^{\circ}$ semestre 2009, pp. 621-638. 
, "Una teoría de la justicia para el cuidado sanitario: la protección de la salud en la Constitución después de la reforma AUGE", Revista de Derecho (Valdivia), vol. XXIII, No2, diciembre 2010, pp. 113-130.

, El derecho a la vida y el derecho a la protección de la salud en la Constitución: una relación necesaria, Estudios Constitucionales, Año 9, № 1, 2011, pp. 37-64.

, "Justicia y racionamiento sanitario en el Plan AUGE: dilemas bioéticos asociados a la distribución de recursos escasos", Acta Bioethica 2011; 17 (1), pp. 73-84.

"Jurisprudencia del Tribunal Constitucional acerca de Derechos Económicos, Sociales y Culturales", Revista de Derecho del Consejo de Defensa del Estado, No 20, 2008, pp. 83-109.

\section{Jurisprudencia citada}

Farmacias Ahumada, Farmacias Cruz Verde, Comercial Salco y Farmacias Brand, Comisión Resolutiva Antimonopolio, condena por conductas de colusión, 16 de mayo de 1995. En: http://www.fne.gob.cl/jurisprudenciaen-libre-competencia/decisiones-comisiones-antimonopolio/ [visitado el 04/03/2013].

Fiscalía Nacional Económica con Farmacias Ahumada S.A., Farmacias Cruz Verde S.A. y Farmacias SalcoBrand S.A., Tribunal de Defensa de la Libre Competencia, Requerimiento por conductas Colusorias, 31 de enero de 2012, http://www.tdlc.cl/Portal.Base/Web/VerContenido.aspx?ID=1829 [visitado el 04/03/2013].

Fiscalía Nacional Económica con Farmacias Ahumada S.A., Farmacias Cruz Verde S.A. y Farmacias Salco Brand S.A., Corte Suprema, Requerimiento por Conductas Colusorias, 7 de septiembre del 2012, http://suprema.poderjudicial.cl/SITSUPPORWEB/InicioAplicacion.do [visitado el 04/03/2013].

Tribunal Constitucional, Inconstitucionalidad iniciada de oficio en relación al artículo 38 ter de la Ley No 18.933, 6 de agosto de 2010, En: http://www.tribunalconstitucional.cl/wp/expedientes/buscador-de-expedientes?rol=1710wsdefrtg [visitado el 07/03/2013]. 